\title{
Associations of Thrombotic-Hemostatic Factors with Cardiovascular Disease
}

\author{
E.L. Lioudaki and E.S. Ganotakis*
}

Department of Internal Medicine, University of Crete and School of Medicine, P. O. Box: 1352, Heraklion 71110, Crete, Greece

\begin{abstract}
Cardiovascular disease (CVD) remains a leading cause of global morbidity and mortality despite identification of major cardiovascular (CV) risk factors and risk reduction via appropriate interventions. During the last years several markers have been studied as potential predictors of CV events. Hemostatic and thrombotic factors such as fibrinogen, homocysteine, factor VII, von Willebrand, tissue plasminogen activator, plasminogen activator inhibitor - 1, D-dimer and lipoprotein $(\alpha)$ have been found to be closely related to CVD. Many epidemiological studies have indicated that raised levels of these factors are associated with higher incidence of CVD, while some others have yielded conflicting results. As a consequence, it remains obscure whether they contribute to prediction of future CV events on top of conventional risk factors. Although data suggest that most of them are somehow implicated in CVD pathophysiology, it is not clearly defined yet whether treatment of abnormal levels leads to $\mathrm{CV}$ risk reduction. As a result measurement and treatment of these factors are justified only in exceptional cases. Further investigation is required in order to conclude whether and which of these factors may claim a position in everyday clinical practice.
\end{abstract}

Keywords: Cardiovascular disease, hemostatic factors, thrombotic factors, review.

\section{INTRODUCTION}

Cardiovascular disease (CVD) is a leading cause of global morbidity and mortality. In 2004, CVD accounted for 17.1 million deaths worldwide [1]. According to the last WHO report, it is believed that by 2030, as many as 23.4 million people will die annually due to CV causes [2].

The identification of major cardiovascular (CV) risk factors was an advance of pivotal importance in terms of primary prevention [3]. Individual risk assessment was enabled, and through interventions on modifiable risk factors, $\mathrm{CV}$ risk reduction can be achieved [3]. However, CV events occur even in subjects without these established risk factors. This, in conjunction with the growing burden of CVD as well as the in-depth understanding of atherosclerosis pathophysiology have led to the quest of novel risk factors in order to enhance primary and secondary prevention. During the last years, several markers have been studied and proposed as predictors of $\mathrm{CV}$ events. These include inflammatory markers, hemostatic - thrombotic factors, lipid-related and various other factors. This review will focus on the relationship of hemostatic and thrombotic factors and CVD.

\section{Fibrinogen (Fib)}

\section{Plasma Levels Determinants}

Fib is a key component of the blood coagulation system and an acute phase reactant. Fib is produced by the liver and

*Address correspondence to this author at the Department of Internal Medicine, University Hospital of Crete, P. O. Box: 1352, Heraklion 71110, Crete, Greece; Tel: +302810392360; Fax: +302810392847;

E-mail: ganotak@med.uoc.gr is a large soluble glycoprotein found in the plasma, consisting of two identical subunits. Each subunit is comprised of three polypeptide chains alpha, beta and gamma linked to each other by disulfide bonds [4].

Plasma Fib levels are determined by both genetic and environmental factors. Advancing age, smoking, obesity, hypertension, dyslipidemia, physical inactivity, menopause, low socio-economic status, oral contraception, female sex and black race are associated with elevated Fib levels [4]. The relationship between smoking and Fib levels is dosedependent according to the number of cigarettes smoked [5]. This effect is reversible upon smoking cessation [5]. On the other hand there are some factors related to lower Fib levels such as moderate alcohol consumption, hormone replacement therapy, regular exercise and weight reduction [4].

\section{Fib \& CVD}

Elevated Fib levels were first reported to correlate with CVD and coronary heart disease (CHD) in particular, almost 60 years ago [6-8]. During the following decades, numerous epidemiologic studies showed a definite relation of Fib to CVD [9-17]. The causality still remains uncertain. The first meta-analysis which recognized Fib levels as an independent $\mathrm{CV}$ risk factor included six prospective epidemiologic studies. Elevated levels were associated with subsequent myocardial infarction (MI) or stroke [odds ratio in the upper vs. lower tertile varying between 1.8 (95\% CI 1.2-2.5) and 4.1(95\% CI 2.3-6.9)] [18]. A latter meta-analysis of 22 studies - including the former six - confirmed the previous findings [19]. It was also emphasized that raised plasma Fib levels are associated with increased CV risk in healthy as much as in high-risk individuals [19]. A recent meta-analysis of 31 
prospective studies including 154, 211 apparently healthy individuals showed that long-term increases in plasma Fib levels of $1 \mathrm{~g} / \mathrm{L}$ are associated with an approximate doubling of risk of major CVD [20].

The causal relevance of elevated Fib levels with disease was assessed in a latter meta-analysis [21]. Approximately one third of the variation in Fib levels was explained by age, sex and cohort [21]. An additional 7\% was accounted for by established risk factors [smoking, body mass index (BMI), high density lipoprotein (HDL)-cholesterol] and a further $10 \%$ was explained by inflammatory markers [notably $\mathrm{C}$ reactive protein - (CRP)] [21]. Furthermore, high plasma Fib concentration has been independently associated with subclinical CVD in the subsequent decade [22] and premature development of CHD in young individuals aged 25-37 and $<$ 45 years respectively [23]. Among blood viscosity major determinants, Fib emerged as the only remaining significantly associated with $\mathrm{CV}$ events and total mortality after adjustment for conventional risk factors [24, 25]. Finally, some studies have reported that Fib levels also correlate with the severity of the underlying CHD [26].

\section{Fib \& Peripheral Arterial Disease (PAD)}

Studies on atherosclerosis in vascular grafts of PAD patients suggested an important role of Fib in PAD [27, 28]. Subsequent epidemiological data demonstrated an independent association of Fib with future PAD development [29-36] and the severity of disease $[37,38]$. This association seems to be stronger among diabetic patients [39]. Furthermore, high plasma concentration has emerged as the strongest predictor of coronary death and all - cause CV mortality in patients with PAD [40].

Besides a potential pathogenetic role in PAD [41, 42], Fib is also significantly associated with the development of restenosis at the site of percutaneous transluminal angioplasty (PTA) [43, 44]. Resolution of critical limb ischemia results in a decrement of Fib levels, without reaching values seen in population controls [44]. This finding implies that elevated Fib is probably a causal factor and not just a consequence of tissue ischemia.

\section{Additional Predictive Value}

It remains unclear whether Fib provides additional predictive value to conventional risk factors regarding future $\mathrm{CV}$ events. The Caerphilly Study concluded that Fib has the potential to increase the prediction of CHD and ischemic stroke in middle-aged men, on top of conventional risk factors [45], confirming previous findings [19]. Another study showed that high Fib levels remain independently predictive of the risk of mortality after adjustment for the Framingham score [46]. However, this study included individuals examined in a high-risk preventive cardiology clinic, so the possibility of bias cannot be excluded. In a substudy of the AngloScandinavian Cardiac Outcomes Trial (ASCOT) on hypertensive patients, Fib emerged as a strong independent predictor of Framingham CHD and stroke risk $(\mathrm{p}<0.0001)$, the number of individual risk factors and Pocock cardiovascular death risk $(p<0.0001)$ [47]. Nevertheless, the AtheroGene Study showed that Fib, even though predictive for future cardiovascular risk in patients with documented CHD, did not provide any further information on top of that obtained from models including traditional risk factors [48]. Simi- larly, in the Edinburgh Artery Study, even though Fib was significantly associated with incident CVD after adjustment not only for conventional CVD risk factors but also for a measure of subclinical disease (ankle brachial index), very little prognostic information individually over and above traditional risk factors assessment was provided [49]. Finally, in the PRIME Study, Fib lost its significance as predictor for MI and coronary death after adjustment for conventional risk factors and inflammatory markers [50].

\section{Fib \& CVD Pathophysiology}

Fib has been detected in plaques and it is thought to promote atherosclerosis $[51,52]$. Except for its role in the coagulation cascade being the precursor of fibrin, Fib exhibits a number of other functions. It stimulates platelet aggregation, increases blood viscosity, promotes smooth muscle proliferation and migration and regulates cell adhesion and chemotaxis $[3,53]$. These may be the mechanisms through which Fib participates in vascular disease. Furthermore, the effect of elevated Fib levels on atherosclerosis may be mediated by inflammation through its role as an acute phase reactant [54].

\section{Fib-Lowering Strategies}

High Fib levels can be reduced through lifestyle interventions. Smoking cessation is associated with a decrement of approximately $0.15 \mathrm{~g} / \mathrm{L}$ in plasma Fib [55]. Moderate alcohol consumption [56], regular exercise [57] and loss of excess body weight [58] are also accompanied by reduction in circulating Fib.

Several medications have been reported to possess Fiblowering properties. This effect is more evident with bezafibrate [58-60], fenofibrate [61, 62] and ciprofibrate [63], but not with gemfibrozil $[61,64]$. Other drugs with a Fiblowering effect are angiotensin converting enzyme inhibitors (ACEI) [65], angiotensin receptor blockers (ARB) [66], $\beta$ blockers $[66,67]$ and ticlopidine [68]. Despite significant reductions sporadically reported in some pravastatin studies [69-71], Fib-lowering action of statins is disputable [72]. Studies on PAD patients showed that the use of vasodilators [73], rheological [74] and thrombolytic [75, 76] agents leads to reduced Fib levels, usually accompanied by clinical improvement.

There are not available any specific Fib-lowering drugs yet. It remains unclear whether a reduction of Fib plasma concentration has a certain beneficial impact on clinical outcome. The development of such drugs would allow the conduction of randomized controlled trials evaluating the actual effect of Fib reduction on cardiovascular disease.

\section{Homocysteine (Hcy)}

Hcy is a thiol-containing amino acid and is an intermediate product in the metabolism of one of the essential amino acids, methionine [77]. Plasma levels of Hcy are determined by diet [78], genetic factors [77], renal function [79] and certain drugs [80]. Normal plasma concentrations range from 5 to $15 \mu \mathrm{mol} / \mathrm{L}$ [81]. Hcy levels from 15 to $30 \mu \mathrm{mol} / \mathrm{L}$ are classified as moderate hyperhomocysteinemia (hyper-Hcy), from 30 to $100 \mu \mathrm{mol} / \mathrm{L}$ as intermediate and levels higher than $100 \mu \mathrm{mol} / \mathrm{L}$ as severe hyper-Hcy [81]. Moderate hyperHcy is a frequent condition in the general population ranging from 5 to $10 \%$ among healthy adults [82] and from 20 to 
$40 \%$ among patients with MI [83], stroke [83] and venous thromboembolism [84] depending on the folate content of their diet.

Deficiency in folate, vitamin $\mathrm{B}_{6}$ and $\mathrm{B}_{12}$, smoking, lack of physical exercise, coffee consumption, increasing age, male gender and menopause have been associated with elevated concentrations of Hcy [78, 85, 86]. Chronic alcoholism is often accompanied by moderate hyper-Hcy [87] while moderate alcohol consumption is associated with reduced Hcy levels [88]. Several disease entities (such as end-stage renal failure, inflammatory bowel disease and hypothyroidism) are frequently accompanied by hyper-Hcy [89-91]. Finally, plasma Hcy is determined by genetic alterations in enzymes and molecules involved in Hcy metabolism [84, 92].

\section{Hcy and CVD}

The detection of atherosclerotic lesions in individuals with inborn errors of Hcy metabolism provided the first evidence for a possible connection of Hcy with CVD [93]. Since then, the association of hyper-Hcy with CVD has been repeatedly demonstrated in both animal [94] and prospective human studies $[83,95,96]$. Data indicate a graded correlation between Hcy levels and the risk or severity of CVD [97].

The first large meta-analysis, including 27 studies, showed that an increment of $5 \mu \mathrm{mol} / \mathrm{L}$ in Hcy levels leads to a rise of CHD risk proportional to that caused by an elevation of $20 \mathrm{mg} / \mathrm{dl}$ in total cholesterol [98]. It was suggested that a reduction of Hcy levels through higher folate intake may prove protective against atherosclerosis [98]. Furthermore, two prospective cohort studies found that high plasma Hcy levels were a strong predictor of mortality in patients with CHD [99] and those with aortic valve stenosis [100]. Nevertheless, a latter meta-analysis of prospective studies suggested that the value of elevated Hcy as a predictor of CHD and stroke in healthy populations is only modest [83]. A $25 \%$ reduction in Hcy levels (about $3 \mu \mathrm{mol} / \mathrm{L}$ ) was associated with an $11 \%(\mathrm{OR}, 0.89 ; 95 \% \mathrm{CI}, 0.83-0.96)$ lower CHD risk and $19 \%(\mathrm{OR}, 0.81 ; 95 \% \mathrm{CI}, 0.69-0.95)$ lower stroke risk, after adjustment for conventional risk factors [83].

Another large meta-analysis of 72 genetic and 20 prospective studies concluded that the relationship between Hcy and CVD is causal [95]. It was suggested that lowering Hcy levels by $3 \mu \mathrm{mol} / \mathrm{L}$ (by increasing folic acid intake) would reduce the risk of CHD by $16 \%$, deep vein thrombosis by $25 \%$ and stroke by $24 \%$ [95]. Finally, in some studies raised Hcy levels emerged as a strong predictor of adverse clinical outcomes in patients with acute coronary syndromes (ACS) [101-103].

\section{Pathophysiology}

Hyper-Hcy is implicated in CVD pathophysiology via more than one way [104]. It is associated with, increased oxidative stress status, augmented thrombogenicity, activation of inflammatory processes, impaired endothelial function, enhanced platelet aggregation and adhesion, altered gene expression (due to DNA methylation) and increased vascular smooth muscle cells proliferation $[77,104]$.

\section{Treatment}

Folic acid, vitamin $B_{6}$ and vitamin $B_{12}$ are required for Hcy metabolism [77]. Mediterranean diet, including food rich in B-vitamins and folic acid, is associated with lower plasma Hcy $[105,106]$. Administration of folic acid and Bvitamins reduces Hcy plasma concentrations in the general population $[107,108]$. Intake of $400 \mu \mathrm{g}$ of folic acid (dose equal to RDA) daily is associated with a $25-30 \%$ reduction of $\mathrm{HCy}$ levels [107]. Co-administration with $\mathrm{B}_{12}(0.02-1$ $\mathrm{mg} /$ day) offers an additional $7 \%$ reduction [108].

However, data regarding the effect of Hcy lowering strategies on CVD are conflicting. A meta-analysis of eight randomised trials showed that folic acid supplementation significantly reduced the risk of stroke in primary prevention by $18 \%$ (RR $0.82,95 \%$ CI $0.68-1.00 ; p=0.045$ ) [109]. In addition, a population based cohort study in Canada and the United States demonstrated that folic acid fortification of food results in an improvement in stroke mortality [110]. Furthermore, Hcy lowering regimens significantly reduce $\mathrm{CV}$ risk in patients with cystathionine beta synthase deficiency despite imperfect biochemical control [111].

On the other hand, several secondary prevention trials have failed to confirm the beneficial effect of Hcy-lowering strategies on CVD clinical outcomes [112-114]. In some cases, this was attributed to deficiencies in the design of trials such as short treatment duration $[115,116]$.

The Heart Outcomes Prevention Evaluation (HOPE) 2 trial indicated that lowering of Hcy with folic acid and vitamins $B_{6}$ and $B_{12}$ did reduce the risk of overall stroke, but not stroke severity or disability [117]. This is consistent with overall evidence implying that the role for Hcy as a CV risk factor is stronger for stroke than for CHD, and possibly strongest for the primary prevention of stroke [117]. However, regardless the effect on CVD clinical outcomes, Hcy lowering has been associated with plaque regression. Several short-term intervention trials have reported improvement of carotid intima media thickness (cIMT) and flow-mediated dilation (FMD) by Hcy lowering strategies, while long-term Hcy lowering has not been found to significantly improve FMD or cIMT in people with a history of stroke [118].

Evidence so far can not justify pharmacological treatment with folate and B vitamins in general population [119]. Hcylowering treatment should be considered in cases of hyperHcy [104]. Reversal of the cause (eg. diet, hypothyroidism, drugs etc) is the best treatment for moderate and intermediate hyper-Hcy [104]. Howevere there is insufficient data to support that pharmacological treatment of moderate hyper-Hcy with folic acid alone or in combination with vitamins $\mathrm{B}_{12}$ and $\mathrm{B}_{6}$, would definitely reduce CV risk. Nevertheless, it is indicated at least in certain cases and most patients respond well [120].

\section{Factor VII (FVII)}

FVII is an enzyme of the serine protease class. It is activated by tissue factor, transforming from a single chain zymogen into a two-chain form. FVII plays an important role in initiating the process of coagulation [121]. There is a positive correlation between FVII levels and BMI, blood pressure, age, postmenopausal status in women and plasma glu- 
cose, insulin and triglyceride concentrations [122]. The association with hypertriglyceridemia is the most powerful one and remains strong and significant after adjustment for conventional risk factors [123].

Although there is evidence supporting an association of FVII with CVD, results from various studies are inconsistent. Elevated FVII levels have been repeatedly reported in CVD patients [124-127]. Northwick Park Heart Study (NPHS)-I demonstrated a dose-dependent relation between FVII concentrations and CHD events as well as total mortality [128] which was not observed in NPHS-II [129]. In addition, FVII antigen levels measured on admission emerged as an independent predictor of mortality and reinfarction in patients with acute MI [130]. On the contrary, the PROCAM study failed to confirm such a relation [131]. Interestingly, multivariate analysis of the Caerphily Prospective Study showed an inverse association of factor VIIc with CVD [45]. Although this may be a chance finding, a similar inverse association was observed in the NPHS-II [129]. As a result, the role of FVII in the development of CVD remains controversial.

\section{4. von Willebrand (vW)}

$\mathrm{vW}$ is a large glycoprotein secreted into the circulation by endothelial cells. Its levels are raised under conditions of endothelial damage. Therefore, its use as a marker of endothelial dysfunction has been suggested. $\mathrm{vW}$ release can be induced by a variety of stimuli such as hypoxia, inflammatory cytokines, histamine, thrombin, leukocyte elastase, endotoxin, exercise, adrenaline and vasopressin, both in vitro and in vivo [132].

vW has three important roles in hemostasis. First, activated $\mathrm{vW}$ binds to platelets mediating their aggregation and adhesion to the vascular wall, especially under conditions of high shear stress. Second, vW serves as a carrier protein for factor VIII. Third, vW binding to collagen in the subendothelial connective tissue leads to a structural change within the factor VIII- binding motif of VWF that lowers the affinity for factor VIII. Enhanced release of FVIII locally may promote fibrin clot formation. This is more important in cases of injury and denudation of endothelium as in ACS [132].

Advancing age is associated with higher vW levels [132]. This may be explained by age-related arterial stiffness leading to increased vW endothelial secretion [133]. Furthermore, $\mathrm{vW}$ release is induced by inflammatory cytokines and raised levels accompany several inflammatory disorders $[132,134]$. A positive correlation between $\mathrm{vW}$ and CRP has been reported in large clinical studies [135, 136]. Type 2 diabetes mellitus (DM), insulin resistance, smoking, hypercholesterolemia and hypertension are also associated with elevated vW levels [137-139]. Moreover, vW plasma levels have been inversely associated with flow mediated dilation [140]. Thus, it has been suggested that $\mathrm{vW}$ increase is a result of impaired NO production. Finally, as much as $75 \%$ of the variance of $\mathrm{vW}$ plasma levels is attributed to genetic factors [132].

Studies have failed to establish $\mathrm{vW}$ as a strong predictor of CHD events in the general population. Most of them have demonstrated weak associations of $\mathrm{vW}$ levels with the risk of
CHD, turning into insignificant after adjustment for conventional risk factors [23, 30, 135, 137, 141-143]. A large prospective study yielded encouraging results showing a moderately significant association between $\mathrm{vW}$ and CHD even after adjustment for baseline values of classical risk factors (OR in the top vs. the bottom third $1.82,95 \%$ CI 1.37-2.41) [144]. Moreover, the PRIME study showed a 3.04-fold increase in the risk of MI and coronary death in patients with plasma vW levels in the highest vs. the lowest quartile $(95 \%$ CI, 1.59 to 5.80) [145].

Interestingly, the association of $\mathrm{vW}$ levels with CVD is stronger with ischemic stroke [146] and PAD [147]. In addition, vW seems to be more closely related to CVD risk in high-risk populations such as diabetic, hypertensive or cardiovascular patients $[48,144,148]$. Furthermore, several studies including MI survivors have described an association of raised $\mathrm{vW}$ levels with reinfarction or/and mortality risk [149152]. Another interesting aspect of the $\mathrm{vW}$ case is the typical time-related increase of its levels during an acute cardiovascular event. This increase has been shown to be an independent predictor of short-term adverse clinical outcome in these patients $[153,154]$. Finally, vW has been reported to be independently associated with surrogates of atherosclerosis (cIMT and microalbuminuria) [155]. Therefore, it was suggested that $\mathrm{vW}$ might represent a valuable systemic biomarker of subclinical atherosclerosis.

In conclusion, current data does not support the use of vW levels as a predictor of CVD in clinical practice. Further data on the value of $\mathrm{vW}$ in the prediction of CVD events other than CHD, especially stroke, are required.

\section{Tissue Plasminogen Activator (tPA), Plasminogen Ac- tivator Inhibitor-1 (PAI-1)}

tPA is a glycoprotein, produced and released mainly by vascular endothelial cells. It is a serine proteinase that mediates the transformation of plasminogen to plasmin, playing a key role in the process of fibrinolysis. PAI-I is produced by the liver, adipose tissue and possibly the endothelium. It is a member of the superfamily of serine proteinase inhibitors [156]. It forms a complex with tPA and inactivates it in order to prevent excessive fibrinolysis and its hazardous complications. Free active tPA is difficult to measure in plasma. Therefore, measurements usually concern circulating tPA antigen values. This is mostly a measure of complex formation between these two factors. High tPA antigen values reflect low tPA activity [156].

Multiple factors can modify t-PA and PAI-1 levels. Regular physical exercise and moderate alcohol consumption promote fibrinolysis, increasing tPA activity and decreasing PAI-1 and tPA antigen levels [157]. Fibrinolytic capacity can be seriously diminished by smoking, atherosclerosis, advancing age, heavy or binge alcohol intake and obesity [157-159]. BMI and waist/hip ratio correlate positively with t-PA and PAI-1 antigen values, while estrogen is inversely associated with tPA and PAI-1 antigen values [157].

Insulin, free fatty acids, triglycerides and both oxidized and glycated low density lipoprotein (LDL) (all raised in IR/type 2 DM) as well as lipoprotein (Lp) ( $\alpha$ ) and inflammatory mediators may induce PAI- 1 expression through apparently independent signalling pathways [121, 122, 160]. Activation of the renin - angiotensin system (RAS) also increases 
PAI-1 expression. This effect is primarily mediated by angiotensin type-1 receptor [161], but there is evidence indicating that renin augments PAI-1 expression too [162].

t-PA release is stimulated by factors such as substance $P$, bradykinin, cytokines [e.g. tumor necrosis factor (TNF) $-\alpha$ ] [156]. Finally, there is a genetic influence on fibrinolysis [121]. Certain polymorphisms are associated with higher tPA and PAI-1 levels [121].

\section{tPA, PAI-1 and CVD}

tPA antigen and PAI-1 have been positively associated with CV events $[45,122,137,163,164]$. In some studies, however, these associations failed to arise as independent of other CV risk factors [165]. The two most frequently studied genetic variants of tPA and PAI-1, have been reported to correlate with increased CV risk, but findings were not further confirmed [166-168].

A meta-analysis of 13 prospective studies examined the relationship between tPA antigen values and CHD [165]. Seven of these studies included samples from the general population, while the rest referred to patients with diagnosed CHD or PAD. Adjustment for baseline values of conventional risk factors led to reductions of odds ratios adjusted for age and sex only [odds ratio of 2.18 (95\% CI 1.77-2.69) in the top third vs. bottom third reduced to 1.47 (95\% CI 1.19-1.81) for the former seven studies and odds ratio of 3.23 (95\% CI $1.71-6.09$ ) reduced to 1.32 (95\% CI 0.70 2.50) for the latter six] [165]. The role of PAI-1 in predicting coronary events has been partly attributed to its association with insulin resistance [169-171].

Several studies have reported low t-PA and, more frequently, high PAI-1 values in PAD patients [172]. Impaired fibrinolysis appears to play a role in the future development of PAD in patients with type 2 DM [173]. Interestingly, the grade of fibrinolysis impairment has been reported to correlate with the severity of claudication [174]. Finally, PAI-1 activity measured 24 and 48 hours after PTA in PAD patients emerged as the only significant predictor of restenosis [175].

\section{Impaired Fibrinolysis and Pathophysiology of CVD}

The causal relationship between impaired fibrinolysis and atherogenesis has not been fully addressed. It is hypothesized that these two processes cooperate and interact resulting in vascular damage [158]. Increasing coronary atheroma burden has been associated with diminished coronary release of active tPA as well as an increase in PAI-1 plasma concentrations in cigarette smokers, implying a direct link between atherosclerosis and impaired acute fibrinolytic capacity [158]. The proposed responsible mechanisms are chronic endothelial cell injury, impairment of the L-arginine nitric oxide pathway and depletion of endothelial cell tPA stores due to chronic stimulation and upregulation of the release [158].

PAI-1 is highly expressed in atherosclerotic lesions [176]. Its raised levels limit fibrinolysis and facilitate thrombosis [177]. Moreover, high PAI-1 levels attenuate migration of vascular smooth muscle cells at sites of vascular injury [178]. This results in the formation of vulnerable, acellular atheromatic plaques, the rupture of which can trigger an ACS [178]. Furthermore, it has been shown that overexpres- sion of PAI-1 in transgenic mice facilitates the formation and persistence of microthrombi containing clot-associated mitogens [179]. Atherothrombosis is favoured and coronary clots may develop, giving rise to coronary events in the absence of typical atherosclerotic background such as hypertension and hyperlipidemia [180].

It has been suggested that levels of tPA and PAI-1 may be more closely related to the presence and severity of atherosclerosis rather than to an upcoming CV event [180]. The association of tPA/PAI-I with subclinical atherosclerosis has been described as one of intermediate significance (compared with the respective relation of fibrinogen to subclinical atherosclerosis which is described as strong) [181].

\section{Strategies to Improve Fibrinolytic Capacity}

Normal function of the fibrinolytic system is affected by multiple factors. Proper modification of these factors can prove helpful in terms of impaired fibrinolysis. This may be achieved through either lifestyle intervention measures or pharmacologic agents or both. Regular physical exercise, moderate alcohol consumption, smoking cessation, weight loss (by regular exercise or/and dietary modifications), amelioration of hypertriglyceridemia (either by dietary changes or treatment with gemfibrozil) are accompanied by favourable effects on fibrinolysis [157]. It has been suggested that the rise in tPA activity through exercise is propionate to exercise intensity but temporary $[182,183]$.

The effect of n-3 PUFA intake on fibrinolysis remains unclear. Studies have yielded inconsistent results, demonstrating either improvement [184] or impairment [185] or even no effect [186] on fibrinolysis.

Lipid lowering agents, pharmacologic inhibition of the RAS [161], improvement of insulin sensitivity and glucose metabolism [187,188] can reduce raised PAI-1 and enhance impaired fibrinolysis. Treatment with ACEI is associated with reductions in PAI-1 levels and a lower incidence of ischemic CV events [189]. This effect is augmented by coadministration of spironolactone [190]. Statins also favour fibrinolysis increasing t-PA and reducing PAI-1 levels [191193]. This is only merely attributed to their lipid - lowering action. Statins appear to modify signalling pathways [inhibit Rho family proteins and activate phosphatidylinositol (PI)-3 kinase/Akt] which are implicated in inflammation mediated induction of PAI-1 expression [194].

\section{D-dimer}

D-dimer is the product of cross-linked fibrin primary degradation [195]. Therefore, its levels represent a measure of ongoing fibrin turnover, reflecting activated coagulation and fibrinolysis [195]. Increasing age and female sex have been correlated with higher D-dimer levels [196-198].

D-dimer has been consistently associated with incident CVD [30, 40, 199-201]. Substantially elevated D-dimer levels have been reported in patients with ACS [202-204]. A meta-analysis of six prospective studies yielded a combined OR of 1.7 for CHD in individuals in the top vs. those in the bottom third baseline D-dimer values (95\% CI, 1.3 to 2.2 ) [199]. In the Caerphilly study, D-dimer was found to have the potential to increase the prediction of CHD or ischemic stroke in middle-aged men in addition to conventional risk factors [45]. Both pathological and clinical studies have in- 
dicated significant correlations between D-dimer and the severity of atherosclerosis, especially in terms of PAD [147, 197, 205]. Thus, it is suggested that local degradation of cross-linked fibrin may be involved in the progression of atherosclerosis.

A relationship between D-dimer and inflammation has also been postulated. D-dimer levels have been repeatedly associated with CRP and IL-6 [199, 200, 206, 207]. In fact, it appears that the combination of D-dimer and CRP is an even more powerful predictor of CVD [207].

These associations may derive from the effect of D-dimer (and other fibrin degradation products) on secretion of IL-6, which, in turn, stimulates hepatic synthesis of acute-phase proteins including CRP [206]. The predictive value of CRP for CVD is attenuated when classic risk factors such as age and smoking are included in multivariate analyses [135, 207]. In contrast, adjustment for these factors has little effect on the association of D-dimer with CV risk, since D-dimer is only weakly related to them [206, 207].

Nevertheless, there is inadequate evidence implying that D-dimer levels provide additional predictive value on top of that obtained from established risk factors. Thus, the use of D-dimer levels in CV risk assessment remains unjustified.

\section{Lipoprotein $(\alpha)[\operatorname{Lp}(\alpha)]$}

$\mathrm{Lp}(\mathrm{a})$ is a particle that resembles LDL in terms of its lipid composition and apolipoprotein (apo) B 100 [208]. The unique component of $\operatorname{Lp}(\alpha)$ is its apo $(\alpha)$ moeity, a glycoprotein similar to plasminogen, bound to apo B100 with a disulfide bond [208]. The biological function of $L p(\alpha)$ remains elusive, even though a role in wound healing has been suggested [209]. Concentrations of $\operatorname{Lp}(\alpha)$ are not related to those of other lipoproteins and apolipoproteins or factors known to influence them such as diet and exercise. $\operatorname{Lp}(\alpha)$ levels are largely under genetic control. They vary widely among individuals, depending on the size of the apo $(\alpha)$ isoform present [208]. Raised $\operatorname{Lp}(\alpha)$ levels have been found in patients with chronic renal failure, nephrotic syndrome, DM, cancer and hypothyroidism and menopausal women. Finally, $\operatorname{Lp}(\alpha)$ may increase as part of the acute phase response. In contrast, $\mathrm{Lp}(\alpha)$ values are lower in liver failure and hyperthyroidism [208].

$\operatorname{Lp}(\alpha)$ is considered highly atherogenic. Plasma levels exceeding 20 to $30 \mathrm{mg} / \mathrm{dL}$ have been associated with increased CV risk [210]. It has been suggested that $\operatorname{Lp}(\alpha)$ may be more atherogenic when carrying small apo $(\alpha)$ isoforms (defined as $<22$ kringle-4 repeats) than larger ones [211].

$\mathrm{L} p(\alpha)$ binds to endothelial cells, macrophages, platelets and to the subendothelial matrix and promotes proliferation of vascular smooth muscle cells and chemotaxis of monocytes. Also, $\operatorname{Lp}(\alpha)$ is thought to compete with plasminogen for binding to plasminogen receptors, fibrinogen, and fibrin (due to their structural homology) [208]. Therefore, it may inhibit clot fibrinolysis at sites of tissue injury, in favour of atherothrombosis. Furthermore, $\operatorname{Lp}(\alpha)$ induces the production of PAI-1 and inhibits the secretion of t-PA by endothelial cells. Finally, it represents a rich source of cholesterol at sites of vascular injury. All these properties of $\operatorname{Lp}(\alpha)$ support its role in atherothrombosis [208].
The importance of $\operatorname{Lp}(\alpha)$ regarding the incidence of CVD has been extensively studied. A meta-analysis of 27 prospective studies demonstrated a clear association between $\operatorname{Lp}(\alpha)$ and CHD. The combined analysis yielded an OR of $1.6(95 \%$ CI 1.4 to 1.8$)$ in the top vs. the bottom third of baseline $\operatorname{Lp}(\alpha)$ [212].

A recent large case-control study demonstrated an independent and approximately continuous relationship between $\operatorname{Lp}(\alpha)$ levels and risk of future CHD. Levels of $\operatorname{Lp}(\alpha)$ were highly stable within individuals across many years and only weakly correlated with known risk factors [213]. Furthermore, a significant association of $\operatorname{Lp}(\alpha)$ with premature CHD has been shown. Elevated Lp(a) levels appear to be common among individuals with a family history of premature CHD or in patients presenting with early-onset of CHD [214].

In the Edinburgh Artery Study, $\operatorname{Lp}(\alpha)$ showed modest associations with MI events, but was significantly associated with stroke and PAD [30]. Another study including patients with acute MI showed that high $\operatorname{Lp}(\alpha)$ levels were independently associated with an increased risk of developing events at 6 months and greater CV morbidity and mortality [215]. Interestingly, $\operatorname{Lp}(\alpha)$ levels in diabetic coronary patients have been found to be low and not associated with the incidence of vascular events. In the same study, $\operatorname{Lp}(\alpha)$ was a strong and independent predictor of vascular events in non-diabetic patients (standardized adjusted hazard ratio $(\mathrm{HR})=1.461$ (1.121-1.904); $\mathrm{p}=0.005)$ [216].

Some prospective studies have not confirmed the positive association of $\operatorname{Lp}(\alpha)$ with $\operatorname{CVD}[217,218]$. This may be attributed to the variability in $\operatorname{Lp}(\alpha)$ measurement assays as well as in the atherogenic potential of $\operatorname{Lp}(\alpha)$ particles [219]. For, example, in African Americans, high Lp(a) levels are not usually associated with small apo $(\alpha)$ isoforms [220], explaining why elevated $\operatorname{Lp}(\alpha)$ levels have not been consistently associated with increased CHD risk in this group of people [221].

$\operatorname{Lp}(\alpha)$ is thought to interact with other risk factors and further increase $\mathrm{CV}$ risk. The presence of older age, low HDL, high LDL, hypertension have been accompanied by stronger associations of raised $\operatorname{Lp}(\alpha)$ with CV risk [222].

The measurement of $\operatorname{Lp}(\alpha)$ levels in combination with Fib, albumin and bilirubin levels may prove useful in the prediction of vascular events in high-risk populations [223]. However, routine use of $\mathrm{Lp}(\mathrm{a})$ in CVD risk assessment is not currently recommended not only because of the lack of a standardized assay, but also because of the limited therapeutic options in the treatment of elevated levels [224]. It has been suggested that the measurement of $L p(\alpha)$ levels may be useful in subjects with a family history of premature CHD or in patients with premature CHD and those who develop $\mathrm{CHD}$ in the absence of conventional risk factors [225].

The most effective measure in treatment of high $\operatorname{Lp}(\alpha)$ is apheresis. Niacin [226], trogens [227], fibrates [228] and some antihypertensive drugs [229] have been reported to exert a lowering effect on $\operatorname{Lp}(\alpha)$ while statins [230] have no such action.

So far, there is no data showing that $\operatorname{Lp}(\alpha)$ lowering is accompanied by a reduction of $\mathrm{CV}$ risk. As a result, $\mathrm{Lp}(\alpha)$ 
lowering strategies are not currently recommended in terms of primary or secondary prevention.

\section{CONCLUDING REMARKS}

Hemostasis and thrombosis play a crucial role in CVD pathophysiology. Elevated levels of thrombotic and hemostatic factors are commonly found in CVD patients. The role of most of them in the initiation and progression of atherosclerosis has been elucidated. Furthermore, their measurement may contribute to the prediction of upcoming $\mathrm{CV}$ events on top of conventional risk factors. Nevertheless, there is insufficient data supporting their use in the assessment of $\mathrm{CV}$ risk as part of routine clinical practice. Further studies are needed in order to confirm whether the treatment of these factors' raised levels has the potential to decrease CVD events.

\section{ABBREVIATIONS}

\begin{tabular}{|c|c|}
\hline ACS & $=$ acute coronary syndromes \\
\hline ACEI & $=$ angiotensin converting enzyme inhibitors \\
\hline Apo & $=$ apolipoprotein \\
\hline $\mathrm{ARB}$ & $=$ angiotensin receptor blockers \\
\hline ASCOT & $=$ Anglo-Scandinavian Cardiac Outcomes Trial \\
\hline BMI & $=$ body mass index \\
\hline cIMT & $=$ carotid intima media thickness \\
\hline $\mathrm{CV}$ & $=$ cardiovascular \\
\hline CVD & $=$ cardiovascular disease \\
\hline $\mathrm{CHD}$ & $=$ coronary heart disease \\
\hline DM & $=$ diabetes mellitus \\
\hline FVII & $=$ factor VII \\
\hline Fib & $=$ fibrinogen \\
\hline FMD & $=$ flow-mediated dilation \\
\hline HDL & $=$ high density lipoprotein \\
\hline Hcy & $=$ homocysteine \\
\hline hyper-Hcy & $=$ hyperhomocysteinemia \\
\hline LDL & $=$ low density lipoprotein \\
\hline $\mathrm{Lp}(\mathrm{a})$ & $=$ lipoprotein $(\mathrm{a})$ \\
\hline PAD & $=$ peripheral arterial disease \\
\hline PAI-1 & $=$ plasminogen activator inhibitor -1 \\
\hline PTA & $=$ percutaneous transluminal angioplasty \\
\hline RAS & $=$ renin - angiotensin system \\
\hline $\mathrm{tPA}$ & $=$ tissue plasminogen activator \\
\hline $\mathrm{TNF}$ & $=$ tumor necrosis factor \\
\hline vW & $=$ von Willebrand \\
\hline
\end{tabular}

\section{REFERENCES}

[1] Global burden of disease 2004. World Health Organization, www.who.int/en/

[2] World health statistics 2008. World Health Organization, www.who.int/en/
[3] Wilson, P.W.; D'Agostino, R.B.; Levy, D.; Belanger, A.M.; Silbershatz, H.; Kannel, W.B. Prediction of coronary heart disease using risk factor categories. Circulation, 1998, 97(18), 1837-1847.

[4] Kamath, S.; Lip, G.Y. Fibrinogen: biochemistry, epidemiology and determinants. Q. J. Med., 2003, 96, 711-729.

[5] Ernst, E.; Matrai, A. Abstention from chronic cigarette smoking normalizes blood rheology. Atherosclerosis, 1987, 64, 75-77.

[6] McDonald, L.; Edgill, M. Coagulability of the blood in ischaemic heart disease. Lancet, 1957, 2, 457-460.

[7] Losner, S.; Volk, B.W.; Wilensky, N.D. Fibrinogen concentration in acute myocardial infaction. Arch. Intern. Med., 1954, 93, 231238.

[8] Phear, D.; Stirland, R. The value of estimating fibrinogen and Creactive protein levels in myocardial ischaemia. Lancet, 1957, 2 , 270-275.

[9] Meade, T.W.; Mellows, S.; Brozovic, M.; Miller, G.J.; Chakrabarti, R.R.; North, W.R.; Haines, A.P.; Stirling, Y.; Imeson, J.D.; Thompson, S.G. Haemostatic function and ischaemic heart disease: principal results of the Northwick Park Heart Study. Lancet, 1986 2(8506), 533-537.

[10] Wilhelmsen, L.; Svärdsudd, K.; Korsan-Bengtsen, K.; Larsson, B.; Welin, L.; Tibblin, G. Fibrinogen as a risk factor for stroke and myocardial infarction. N. Engl. J. Med., 1984, 311(8), 501-505.

[11] Stone, M.C.; Thorpe, J.M. Plasma fibrinogen--a major coronary risk factor. J. R. Coll. Gen. Pract., 1985, 35(281), 565-569.

[12] Kannel, W.B.; Wolf, P.A.; Castelli, W.P.; D'Agostino, R.B. Fibrinogen and risk of cardiovascular disease. The Framingham Study. JAMA, 1987, 258(9), 1183-1186.

[13] Kannel, W.B.; D'Agostino, R.B.; Wilson, P.W.; Belanger, A.J.; Gagnon, D.R. Diabetes, fibrinogen, and risk of cardiovascular disease: the Framingham experience. Am. Heart J., 1990, 120(3), 672676.

[14] Yarnell, J.W.; Baker, I.A.; Sweetnam, P.M.; Bainton, D.; O'Brien, J.R.; Whitehead, P.J.; Elwood, P.C. Fibrinogen, viscosity, and white blood cell count are major risk factors for ischemic heart disease. The caerphilly and speedwell collaborative heart disease studies. Circulation, 1991, 83(3), 836-844.

[15] Thompson, S.G.; Kienast, J.; Pyke, S.D.; Haverkate, F.; van de Loo, J.C. Hemostatic factors and the risk of myocardial infarction or sudden death in patients with angina pectoris. European Concerted Action on thrombosis and disabilities Angina Pectoris Study Group. N. Engl. J. Med., 1995, 332(10), 635-641.

[16] Cremer, P.; Nagel, D.; Seidel, D.; van de Loo, J.C.; Kienast, J. Considerations about plasma fibrinogen concentration and the cardiovascular risk: combined evidence from the GRIPS and ECAT studies. Goettingen Risk Incidence and Prevalence Study. European Concerted Action on Thrombosis and Disabilities. Am. J. Cardiol., 1996, 78(3), 380-381.

[17] Cremer, P.; Nagel, D.; Labrot, B.; Mann, H.; Muche, R.; Elster, H.; Seidel, D. Lipoprotein $\mathrm{Lp}(\mathrm{a})$ as predictor of myocardial infarction in comparison to fibrinogen, LDL cholesterol and other risk factors: results from the prospective Göttingen Risk Incidence and Prevalence Study (GRIPS). Eur. J. Clin. Invest., 1994, 24(7), 444453.

[18] Ernst, E.; Resch, K.L. Fibrinogen as a cardiovascular risk factor: a meta-analysis and review of the literature. Ann. Intern. Med., 1993 , 118(12), 956-963.

[19] Maresca, G.; Di Blasio, A.; Marchioli, R.; Di Minno, G. Measuring plasma fibrinogen to predict stroke and MI: an update. Arterioscler. Thromb. Vasc. Biol., 1999, 19, 1368-1377.

[20] The fibrinogen studies collaboration. Plasma fibrinogen level and the risk of major cardiovascular diseases and nonvascular mortality: an individual participant meta-analysis. JAMA, 2005, 294(14), 1799-1809.

[21] Kaptoge, S.; White, I.R.; Thompson, S.G.; Wood, A.M.; Lewington, S.; Lowe, G.D.; Danesh, J. Fibrinogen Studies Collaboration: associations of plasma fibrinogen levels with established cardiovascular disease risk factors, inflammatory markers, and other characteristics: individual participant meta-analysis of 154, 211 adults in 31 prospective studies: the fibrinogen studies collaboration. Am. J. Epidemiol., 2007, 166(8), 867-879.

[22] Green, D.; Foiles, N.; Chan, C.; Schreiner, P.J.; Liu, K. Elevated fibrinogen levels and subsequent subclinical atherosclerosis: the CARDIA Study. Atherosclerosis, 2009, 202(2), 623-631.

[23] Pineda, J.; Marín, F.; Marco, P.; Roldán, V.; Valencia, J.; RuizNodar, J.M.; Sogorb, F.; Lip, G.Y. Premature coronary artery dis- 
ease in young (age <45) subjects: Interactions of lipid profile, thrombophilic and haemostatic markers. Int. J. Cardiol., 2009, 136(2), 222-225.

[24] Woodward, M.; Rumley, A.; Tunstall-Pedoe, H.; Lowe, G.D. Does sticky blood predict a sticky end? Associations of blood viscosity, haematocrit and fibrinogen with mortality in the West of Scotland. Br. J. Haematol., 2003, 122(4), 645-650.

[25] Lowe, G.D.; Drummond, M.M.; Lorimer, A.R.; Hutton, I.; Forbes, C.D.; Prentice, C.R.; Barbenel, J.C. Relation between extent of coronary artery disease and blood viscosity. Br. Med. J., 1980, 280(6215), 673-674.

[26] Handa, K.; Kono, S.; Saku, K.; Sasaki, J.; Kawano, T.; Sasaki, Y; Hiroki, T.; Arakawa, K. Plasma fibrinogen levels as an independent indicator of severity of coronary atherosclerosis. Atherosclerosis, 1989, 77(2-3), 209-213.

[27] Walton, K.W.; Slaney, G.; Ashton, F. Atherosclerosis in vascular grafts for peripheral vascular disease. Part 1. Autogenous vein grafts. Atherosclerosis, 1985, 54, 49-64.

[28] Walton, K.W.; Slaney, G.; Ashton, F. Atherosclerosis in vascular grafts for peripheral vascular disease. Part 2. Synthetic arterial prostheses. Atherosclerosis, 1986, 61, 155-167.

[29] Wattanakit, K.; Folsom, A.R.; Selvin, E.; Weatherley, B.D.; Pankow, J.S.; Brancati, F.L.; Hirsch, A.T. Risk factors for peripheral arterial disease incidence in persons with diabetes: the Atherosclerosis Risk in Communities (ARIC) Study. Atherosclerosis, 2005, 180(2), 389-397.

[30] Tzoulaki, I.; Murray, G.D.; Lee, A.J.; Rumley, A.; Lowe, G.D.; Fowkes, F.G. Inflammatory, haemostatic, and rheological markers for incident peripheral arterial disease: Edinburgh Artery Study. Eur. Heart J., 2007, 28(3), 354-362.

[31] Meijer, W.T.; Grobbee, D.E.; Hunink, M.G.; Hofman, A.; Hoes, A.W. Determinants of peripheral arterial disease in the elderly: the Rotterdam study. Arch. Intern. Med., 2000, 160(19), 2934-2938.

[32] Criqui, M.H.; Denenberg, J.O.; Langer, R.D.; Fronek, A. The epidemiology of peripheral arterial disease: importance of identifying the population at risk. Vasc. Med., 1997, 2(3), 221-226.

[33] Mazoyer, E.; Drouet, L.; Soria, C.; Fruchard, J.C.; Pellerin, A.; Arcan, J.C.; Tobelem, G. Risk factors and outcomes for atherothrombotic disease in French patients: the RIVAGE study. RIsque VAsculaire Group d'Etude. Thromb. Res., 1999, 95(4), 163176.

[34] Roller, R.E.; Janisch, S.; Carroll, V.; Kvas, E.; Pilger, E.; Binder, B.R.; Wojta, J. Changes in the fibrinolytic system in patients with peripheral arterial occlusive disease undergoing percutaneous transluminal angioplasty. Thromb. Res., 1999, 94(4), 241-247.

[35] Stampfer, M.J.; Rifai, N. Novel risk factors for systemic atherosclerosis: a comparison of C-reactive protein, fibrinogen, homocysteine, lipoprotein(a), and standard cholesterol screening as predictors of peripheral arterial disease. JAMA, 2001, 285, 2481-2485.

[36] Smith, F.B.; Lee, A.J.; Hau, C.M.; Rumley, A.; Lowe, G.D.; Fowkes, F.G. Plasma fibrinogen, haemostatic factors and prediction of peripheral arterial disease in the Edinburgh Artery Study. Blood Coagul. Fibrinolysis, 2000, 11, 43-50.

[37] Lassila, R.; Peltonen, S.; Lepantalo, M.; Saarinen, O.; Kauhanen, P.; Manninen, V. Severity of peripheral atherosclerosis is associated with fibrinogen and degradation of cross-linked fibrin. Arterioscler. Thromb., 1993, 13, 1738-1742.

[38] Owens, C.D.; Ridker, P.M.; Belkin, M.; Hamdan, A.D.; Pomposelli, F.; Logerfo, F.; Creager, M.A.; Conte, M.S. Elevated Creactive protein levels are associated with postoperative events in patients undergoing lower extremity vein bypass surgery. J. Vasc. Surg., 2007, 45, 2-9.

[39] Bianchi, C.; Penno, G.; Pancani, F.; Civitelli, A.; Piaggesi, A.; Caricato, F.; Pellegrini, G.; Del Prato, S.; Miccoli, R. Nontraditional cardiovascular risk factors contribute to peripheral arterial disease in patients with type 2 diabetes. Diabetes Res. Clin. Pract., 2007, 78(2), 246-253.

[40] Fowkes, F.G.; Lowe, G.D.; Housley, E.; Rattray, A.; Rumley, A.; Elton, R.A.; MacGregor, I.R.; Dawes, J. Cross-linked fibrin degradation products, progression of peripheral arterial disease, and risk of coronary heart disease. Lancet, 1993, 342, 84-86.

[41] Smith, F.B.; Lowe, G.D.; Fowkes, F.G.; Rumley, A.; Rumley, A.G.; Donnan, P.T.; Housley, E. Smoking, haemostatic factors and lipid peroxides in a population case control study of peripheral arterial disease. Atherosclerosis, 1993, 102(2), 155-162.
[42] Woodburn, K.R.; Lowe, G.D.; Rumley, A.; Love, J.; Pollock, J.G. Relation of haemostatic, fibrinolytic, and rheological variables to the angiographic extent of peripheral arterial occlusive disease. Int. Angiol., 1995, 14(4), 346-352.

[43] Koksch, M.; Zeiger, F.; Wittig, K.; Pfeiffer, D.; Ruehlmann, C. Haemostatic derangement in advanced peripheral occlusive arterial disease. Int. Angiol., 1999, 18(4), 256-262.

[44] Woodburn, K.R.; Rumley, A.; Lowe, G.D.; Pollock, J.G. Fibrinogen and markers of fibrinolysis and endothelial damage following resolution of critical limb ischaemia. Eur. J. Vasc. Endovasc. Surg., 1995, 10(3), 272-278.

[45] Smith, A.; Patterson, C.; Yarnell, J.; Rumley, A.; Ben-Shlomo, Y.; Lowe, G. Which hemostatic markers add to the predictive value of conventional risk factors for coronary heart disease and ischemic stroke? The Caerphilly Study. Circulation, 2005, 112(20), 30803087 .

[46] Acevedo, M.; Pearce, G.L.; Kottke-Marchant, K.; Sprecher, D.L. Elevated fibrinogen and homocysteine levels enhance the risk of mortality in patients from a high-risk preventive cardiology clinic. Arterioscler. Thromb. Vasc. Biol., 2002, 22(6), 1042-1045.

[47] Spencer, C.G.; Felmeden, D.C.; Blann, A.D.; Lip, G.Y. Haemorheological, platelet and endothelial indices in relation to global measures of cardiovascular risk in hypertensive patients: a substudy of the Anglo-Scandinavian Cardiac Outcomes Trial. J. Intern. Med., 2007, 261(1), 82-90.

[48] Sinning, J.M.; Bickel, C.; Messow, C.M.; Schnabel, R.; Lubos, E.; Rupprecht, H.J.; Espinola-Klein, C.; Lackner, K.J.; Tiret, L.; Münzel, T.; Blankenberg, S.; AtheroGene Investigators. Impact of Creactive protein and fibrinogen on cardiovascular prognosis in patients with stable angina pectoris: the AtheroGene study. Eur. Heart J., 2006, 27(24), 2962-2968.

[49] Tzoulaki, I.; Murray, G.D.; Lee, A.J.; Rumley, A.; Lowe, G.D.; Fowkes, F.G. Relative value of inflammatory, hemostatic, and rheological factors for incident myocardial infarction and stroke: the Edinburgh Artery Study. Circulation, 2007, 115(16), 21192127.

[50] Luc, G.; Bard, J.M.; Juhan-Vague, I.; Ferrieres, J.; Evans, A.; Amouyel, P.; Arveiler, D.; Fruchart, J.C.; Ducimetiere, P.; PRIME Study Group. C-reactive protein, interleukin-6, and fibrinogen as predictors of coronary heart disease: the PRIME Study. Arterioscler. Thromb. Vasc. Biol., 2003, 23(7), 1255-1261.

[51] Mosesson, M.W. Fibrinogen and fibrin structure and functions. $J$. Thromb. Haemost., 2005, 3(8), 1894-1904.

[52] Kannel, W.B. Overview of hemostatic factors involved in atherosclerotic cardiovascular disease. Lipids, 2005, 40(12), 1215-1220.

[53] Kakafika, A.I.; Liberopoulos, E.N.; Karagiannis, A.; Athyros, V.G.; Mikhailidis, D.P. Dyslipidaemia, hypercoagulability and the metabolic syndrome. Curr. Vasc. Pharmacol., 2006, 4(3), 175-183.

[54] Tracy, R.P. Inflammation markers and coronary heart disease. Curr. Opin. Lipidol., 1999, 10, 435-441.

[55] Meade, T.W.; Imeson, J.; Stirling, Y. Effects of changes in smoking and other characteristics on clotting factors and the risk of ischaemic heart disease. Lancet, 1987, 2(8566), 986-988.

[56] Wang, Z.; Barker, T.H.; Fuller, G.M. Alcohol at moderate levels decreases fibrinogen expression in vivo and in vitro. Alcohol Clin. Exp. Res., 1999, 23(12), 1927-1932.

[57] Zanettini, R.; Bettega, D.; Agostoni, O.; Ballestra, B.; del Rosso, G.; di Michele, R.; Mannucci, P.M. Exercise training in mild hypertension: effects on blood pressure, left ventricular mass and coagulation factor VII and fibrinogen. Cardiology, 1997, 88(5), 468473.

[58] Ditschuneit, H.H.; Flechtner-Mors, M.; Adler, G. Fibrinogen in obesity before and after weight reduction. Obes. Res., 1995, 3, 4348.

[59] de Faire, U.; Ericsson, C.G.; Grip, L.; Nilsson, J.; Svane, B.; Hamsten, A. Retardation of coronary atherosclerosis: the Bezafibrate Coronary Atherosclerosis Intervention Trial (BECAIT) and other angiographic trials. Cardiovasc. Drugs Ther., 1997, 11(Suppl. 1), 257-263.

[60] Tanne, D.; Haim, M.; Boyko, V.; Goldbourt, U.; Reshef, T.; Matetzky, S.; Adler, Y.; Mekori, Y.A.; Behar, S. Soluble intercellular adhesion molecule-1 and risk of future ischemic stroke: a nested case-control study from the Bezafibrate Infarction Prevention (BIP) study cohort. Stroke, 2002, 33(9), 2182-2186.

[61] Branchi, A.; Rovellini, A.; Sommariva, D.; Gugliandolo, A.G.; Fasoli, A. Effect of three fibrate derivatives and of two HMG-CoA 
reductase inhibitors on plasma fibrinogen level in patients with primary hypercholesterolemia. Thromb. Haemost., 1993, 70(2), 241-243.

[62] Keech, A.; Simes, R.J.; Barter, P.; Best, J.; Scott, R.; Taskinen, M.R.; Forder, P.; Pillai, A.; Davis, T.; Glasziou, P.; Drury, P.; Kesäniemi, Y.A.; Sullivan, D.; Hunt, D.; Colman, P.; d'Emden, M.; Whiting, M.; Ehnholm, C.; Laakso, M. FIELD study investigators:effects of long-term fenofibrate therapy on cardiovascular events in 9795 people with type 2 diabetes mellitus (the FIELD study): randomised controlled trial. Lancet, 2005, 366(9500), 18491861 .

[63] Mikhailidis, D.P.; Ganotakis, E.S.; Spyropoulos, K.A.; Jagroop, I.A.; Byrne, D.J.; Winder, A.F. Prothrombotic and lipoprotein variables in patients attending a cardiovascular risk management clinic: response to ciprofibrate or lifestyle advice. Int. Angiol., 1998, 17(4), 225-233.

[64] Milionis, H.J.; Elisaf, M.S.; Mikhailidis, D.P. Treatment of dyslipidaemias in patients with established vascular disease: a revival of the fibrates. Curr. Med. Res. Opin., 2000, 16(1), 21-32.

[65] Fogari, R.; Zoppi, A.; Lazzari, P.; Preti, P.; Mugellini, A.; Corradi, L.; Lusardi, P. ACE inhibition but not angiotensin II antagonism reduces plasma fibrinogen and insulin resistance in overweight hypertensive patients. J. Cardiovasc. Pharmacol., 1998, 32(4), 616620 .

[66] Makris, T.K.; Stavroulakis, G.A.; Krespi, P.G.; Hatzizacharias, A.N.; Triposkiadis, F.K.; Tsoukala, C.G.; Votteas, V.V.; Kyriakidis, M.K. Fibrinolytic/hemostatic variables in arterial hypertension: response to treatment with irbesartan or atenolol. Am. J. Hypertens., 2000, 13(7), 783-788.

[67] Vyssoulis, G.P.; Marinakis, A.G.; Aznaouridis, K.A.; Karpanou, E.A.; Arapogianni, A.N.; Cokkinos, D.V.; Stefanadis, C.I. The impact of third-generation beta-blocker antihypertensive treatment on endothelial function and the prothrombotic state: effects of smoking. Am. J. Hypertens., 2004, 17(7), 582-589.

[68] Mazoyer, E.; Ripoll, L.; Boisseau, M.R.; Drouet, L. How does ticlopidine treatment lower plasma fibrinogen? Thromb. Res., 1994, 75(3), 361-370.

[69] Lowe, G.; Rumley, A.; Norrie, J.; Ford, I.; Shepherd, J.; Cobbe, S.; Macfarlane, P.; Packard, C. Blood rheology, cardiovascular risk factors, and cardiovascular disease: the West of Scotland Coronary Prevention Study. Thromb. Haemost., 2000, 84(4), 553-558.

[70] Dupuis, J.; Tardif, J.C.; Cernacek, P.; Théroux, P. Cholesterol reduction rapidly improves endothelial function after acute coronary syndromes. The RECIFE (reduction of cholesterol in ischemia and function of the endothelium) trial. Circulation, 1999, 99(25), 3227-3233.

[71] Di Garbo, V.; Bono, M.; Di Raimondo, D.; De Simone, R.; Raneli, G.; Avellone, G. Non lipid, dose-dependent effects of pravastatin treatment on hemostatic system and inflammatory response. Eur. J. Clin. Pharmacol., 2000, 56(4), 277-284.

[72] Balk, E.M.; Lau, J.; Goudas, L.C.; Jordan, H.S.; Kupelnick, B.; Kim, L.U.; Karas, R.H. Effects of statins on nonlipid serum markers associated with cardiovascular disease: a systematic review. Ann. Intern. Med., 2003, 139(8), 670-682.

[73] Davis, E.; Rozov, H. Xanthinol nicotinate in peripheral vascular disease. Practitioner, 1975, 215(1290), 793-798.

[74] Deutschinoff, A.; Grozdinsky, L. Rheological and anticoagulant therapy of patients with chronic peripheral occlusive arterial disease (COAD). Angiology, 1987, 38(5), 351-358.

[75] Bussard, M.E. Reteplase: nursing implications for catheter-directed thrombolytic therapy for peripheral vascular occlusions. Crit. Care Nurse, 2002, 22(3), 57-63.

[76] Razavi, M.K.; Wong, H.; Kee, S.T.; Sze, D.Y.; Semba, C.P.; Dake, M.D. Initial clinical results of tenecteplase (TNK) in catheterdirected thrombolytic therapy. J. Endovasc. Ther., 2002, 9(5), 593598.

[77] Trabetti, E. Homocysteine, MTHFR gene polymorphisms, and cardio-cerebrovascular risk. J. Appl. Genet., 2008, 49(3), 267-282.

[78] Selhub, J.; Jacques, P.F.; Wilson, P.W.; Rush, D.; Rosenberg, I.H. Vitamin status and intake as primary determinants of homocysteinemia in an elderly population. JAMA, 1993, 270(22), 26932698.

[79] van Guldener, C.; Stehouwer, C.D. Homocysteine and methionine metabolism in renal failure. Semin. Vasc. Med., 2005, 5(2), 201208.
[80] Dierkes, J.; Westphal, S. Effect of drugs on homocysteine concentrations. Semin. Vasc. Med., 2005, 5(2), 124-139.

[81] Kang, S.S.; Wong, P.W.; Malinow, M.R. Hyperhomocyst(e)inemia as a risk factor for occlusive vascular disease. Annu. Rev. Nutr., 1992, 12, 279-298.

[82] Lentz, S.R.; Haynes, W.G. Homocysteine: is it a clinically important cardiovascular risk factor? Cleve. Clin. J. Med., 2004, 71(9), 729-734.

[83] Homocysteine studies collaboration. Homocysteine and risk of ischemic heart disease and stroke: a meta-analysis. JAMA, 2002, 288(16), 2015-2022.

[84] Den Heijer, M.; Lewington, S.; Clarke, R. Homocysteine, MTHFR and risk of venous thrombosis: a meta-analysis of published epidemiological studies. J. Thromb. Haemost., 2005, 3(2), 292-299.

[85] Nygård, O.; Refsum, H.; Ueland, P.M.; Vollset, S.E. Major lifestyle determinants of plasma total homocysteine distribution: the Hordaland Homocysteine Study. Am. J. Clin. Nutr., 1998, 67(2), 263-270.

[86] Refsum, H.; Ueland, P.M.; Nygård, O.; Vollset, S.E. Homocysteine and cardiovascular disease. Annu. Rev. Med., 1998, 49, 31-62.

[87] Blasco, C.; Caballería, J.; Deulofeu, R.; Lligoña, A.; Parés, A.; Lluis, J.M.; Gual, A.; Rodés, J. Prevalence and mechanisms of hyperhomocysteinemia in chronic alcoholics. Alcohol Clin. Exp. Res., 2005, 29(6), 1044-1048.

[88] Ubbink, J.B.; Fehily, A.M.; Pickering, J.; Elwood, P.C.; Vermaak, W.J. Homocysteine and ischaemic heart disease in the Caerphilly cohort. Atherosclerosis, 1998, 140(2), 349-356.

[89] Cibulka, R.; Racek, J. Metabolic disorders in patients with chronic kidney failure. Physiol. Res., 2007, 56(6), 697-705.

[90] Koutroubakis, I.E.; Dilaveraki, E.; Vlachonikolis, I.G.; Vardas, E.; Vrentzos, G.; Ganotakis, E.; Mouzas, I.A.; Gravanis, A.; Emmanouel, D.; Kouroumalis, E.A. Hyperhomocysteinemia in Greek patients with inflammatory bowel disease. Dig. Dis. Sci., 2000, 45(12), 2347-2351.

[91] Sengül, E.; Cetinarslan, B.; Tarkun, I.; Cantürk, Z.; Türemen, E. Homocysteine concentrations in subclinical hypothyroidism. Endocr. Res., 2004, 30(3), 351-359.

[92] Jakubowski, H. The pathophysiological hypothesis of homocysteine thiolactone-mediated vascular disease. J. Physiol. Pharmacol., 2008, 59(Suppl. 9), 155-167.

[93] McCully, K.S. Homocystinuria, arteriosclerosis, methylmalonic aciduria, and methyltransferase deficiency: a key case revisited. Nutr. Rev., 1992, 50(1), 7-12.

[94] Lentz, S.R. Mechanisms of homocysteine-induced atherothrombosis. J. Thromb. Haemost., 2005, 3(8), 1646-1654.

[95] Wald, D.S.; Law, M.; Morris, J.K. Homocysteine and cardiovascular disease: evidence on causality from a meta-analysis. $\mathrm{Br}$. Med. J., 2002, 325(7374), 1202.

[96] Vrentzos, G.E.; Papadakis, J.A.; Malliaraki, N.; Zacharis, E.A.; Mazokopakis, E.; Margioris, E.; Ganotakis, E.S.; Kafatos, A. Diet, serum homocysteine levels and ischaemic heart disease in a Mediterranean population. Br. J. Nutr., 2004, 91, 1013-1019.

[97] Vrentzos, G.; Papadakis, J.A.; Malliaraki, N.; Zacharis, E.A.; Katsogridakis, K.; Margioris, A.N.; Vardas, P.E.; Ganotakis, E.S. Association of serum total homocysteine with the extent of ischemic heart disease in a Mediterranean cohort. Angiology, 2004, 55(5), 517-524.

[98] Boushey, C.J.; Beresford, S.A.; Omenn, G.S.; Motulsky, A.G. A quantitative assessment of plasma homocysteine as a risk factor for vascular disease. Probable benefits of increasing folic acid intakes. JAMA, 1995, 274(13), 1049-1057.

[99] Nygård, O.; Nordrehaug, J.E.; Refsum, H.; Ueland, P.M.; Farstad, M.; Vollset, S.E. Plasma homocysteine levels and mortality in patients with coronary artery disease. N. Engl. J. Med., 1997, 337(4), 230-236.

[100] Nygard, O.; Ueland, P.M.; Refsum, H.; Nordrehaug, J.E.; Vollset, S.E. Plasma total homocysteine: a risk factor for mortality in aortic stenosis patients. Neth. J. Med., 1998, 52, S29-S30.

[101] Nevado, J.B. Jr.; Imasa, M.S. Homocysteine predicts adverse clinical outcomes in unstable angina and non-ST elevation myocardial infarction: implications from the folate intervention in non-ST elevation myocardial infarction and unstable angina study. Coron. Artery Dis., 2008, 19(3), 153-161.

[102] Vizzardi, E.; Nodari, S.; Fiorina, C.; Metra, M.; Dei Cas, L. Plasma homocysteine levels and late outcome in patients with unstable angina. Cardiology, 2007, 107(4), 354-359. 
[103] Stubbs, P.J.; Al-Obaidi, M.K.; Conroy, R.M.; Collinson, P.O.; Graham, I.M.; Noble, I.M. Effect of plasma homocysteine concentration on early and late events in patients with acute coronary syndromes. Circulation, 2000, 102(6), 605-610.

[104] Antoniades, C.; Antonopoulos, A.S.; Tousoulis, D.; Marinou, K.; Stefanadis, C. Homocysteine and coronary atherosclerosis: from folate fortification to the recent clinical trials. Eur. Heart J., 2009, $30(1), 6-15$.

[105] Vrentzos, G.E.; Papadakis, J.A.; Malliaraki, N.; Bampalis, D.E.; Repa, A.; Lemonomichelaki, V.; Petinellis, E.G.; Ganotakis, E.S. Serum homocysteine concentration as a marker of nutritional status of healthy subjects in Crete, Greece. J. Hum. Nutr. Diet, 2006, 19, $117-123$.

[106] Chrysohoou, C.; Panagiotakos, D.B.; Pitsavos, C.; Das, U.N.; Stefanadis, C. Adherence to the Mediterranean diet attenuates inflammation and coagulation process in healthy adults: The ATTICA Study. J. Am. Coll. Cardiol., 2004, 44(1), 152-158.

[107] Homocysteine Lowering Trialists' Collaboration. Dose-dependent effects of folic acid on blood concentrations of homocysteine: a meta-analysis of the randomized trials. Am. J. Clin. Nutr., 2005, 82(4), 806-812.

[108] Malinow, M.R.; Bostom, A.G.; Krauss, R.M. Homocyst(e)ine, diet, and cardiovascular diseases: a statement for healthcare professionals from the Nutrition Committee, American Heart Association. Circulation, 1999, 99(1), 178-182.

[109] Wang, X.; Qin, X.; Demirtas, H.; Li, J.; Mao, G.; Huo, Y.; Sun, N.; Liu, L.; Xu, X. Efficacy of folic acid supplementation in stroke prevention: a meta-analysis. Lancet, 2007, 369(9576), 1876-1882.

[110] Yang, Q.; Botto, L.D.; Erickson, J.D.; Berry, R.J.; Sambell, C.; Johansen, H.; Friedman, J.M. Improvement in stroke mortality in Canada and the United States, 1990 to 2002. Circulation, 2006, 113(10), 1335-1343.

[111] Yap, S.; Boers, G.H.; Wilcken, B.; Wilcken, D.E.; Brenton, D.P.; Lee, P.J.; Walter, J.H.; Howard, P.M.; Naughten, E.R. Vascular outcome in patients with homocystinuria due to cystathionine betasynthase deficiency treated chronically: a multicenter observational study. Arterioscler. Thromb. Vasc. Biol., 2001, 21(12), 2080-2085.

[112] Bazzano, L.A.; Reynolds, K.; Holder, K.N.; He, J. Effect of folic acid supplementation on risk of cardiovascular diseases: a metaanalysis of randomized controlled trials. JAMA, 2006, 296(22), 2720-2726.

[113] Albert, C.M.; Cook, N.R.; Gaziano, J.M.; Zaharris, E.; MacFadyen, J.; Danielson, E.; Buring, J.E.; Manson, J.E. Effect of folic acid and B vitamins on risk of cardiovascular events and total mortality among women at high risk for cardiovascular disease: a randomized trial. JAMA, 2008, 299(17), 2027-2036.

[114] Ebbing, M.; Bleie, Ø.; Ueland, P.M.; Nordrehaug, J.E.; Nilsen, D.W.; Vollset, S.E.; Refsum, H.; Pedersen, E.K.; Nygård, O. Mortality and cardiovascular events in patients treated with homocysteine-lowering $\mathrm{B}$ vitamins after coronary angiography: a randomized controlled trial. JAMA, 2008, 300(7), 795-804.

[115] B-Vitamin Treatment Trialists' Collaboration. Homocysteinelowering trials for prevention of cardiovascular events: a review of the design and power of the large randomized trials. Am. Heart J., 2006, 151(2), 282-287.

[116] Saposnik, G.; Ray, J.G.; Sheridan, P.; McQueen, M.; Lonn, E.; Heart Outcomes Prevention Evaluation 2 Investigators. Homocysteine-lowering therapy and stroke risk, severity, and disability: additional findings from the HOPE 2 trial. Stroke, 2009, 40(4), 13651372.

[117] McNulty, H.; Pentieva, K.; Hoey, L.; Ward, M. Homocysteine, Bvitamins and CVD. Proc. Nutr. Soc., 2008, 67(2), 232-237.

[118] Potter, K.; Hankey, G.J.; Green, D.J.; Eikelboom, J.; Jamrozik, K.; Arnolda, L.F. The effect of long-term homocysteine-lowering on carotid intima-media thickness and flow-mediated vasodilation in stroke patients: a randomized controlled trial and meta-analysis. BMC Cardiovasc. Disord., 2008, 8, 24.

[119] Lonn, E.; Yusuf, S.; Arnold, M.J.; Sheridan, P.; Pogue, J.; Micks, M.; McQueen, M.J.; Probstfield, J.; Fodor, G.; Held, C.; Genest, J. Jr.; Heart outcomes prevention evaluation (HOPE) 2 investigators. Homocysteine lowering with folic acid and B vitamins in vascular disease. N. Engl. J. Med., 2006, 354(15), 1567-1577.

[120] Yap, S. Classical homocystinuria: vascular risk and its prevention. J. Inherit. Metab. Dis., 2003, 26(2-3), 259-265.

[121] Ajjan, R.; Grant, P.J. Coagulation and atherothrombotic disease. Atherosclerosis, 2006, 186(2), 240-259.
[122] Pearson, T.A.; LaCava, J.; Weil, H.F. Epidemiology of thrombotichemostatic factors and their associations with cardiovascular disease. Am. J. Clin Nutr., 1997, 65(Suppl. 5), 1674S-1682S.

[123] Balleisen, L.; Assmann, G.; Bailey, J.; Epping, P.H.; Schulte, H.; van de Loo, J. Epidemiological study on factor VII, factor VIII and fibrinogen in an industrial population--II. Baseline data on the relation to blood pressure, blood glucose, uric acid, and lipid fractions. Thromb. Haemost., 1985, 54(3), 721-723.

[124] Balleisen, L.; Schulte, H.; Assmann, G.; Epping, P.H.; van de Loo J. Coagulation factors and the progress of coronary heart disease. Lancet, 1987, 2(8556), 461.

[125] Dalaker, K.; Smith, P.; Arnesen, H.; Prydz, H. Factor VIIphospholipid complex in male survivors of acute myocardial infarction. Acta Med. Scand., 1987, 222(2), 111-116.

[126] Broadhurst, P.; Kelleher, C.; Hughes, L.; Imeson, J.D.; Raftery, E.B. Fibrinogen, factor VII clotting activity and coronary artery disease severity. Atherosclerosis, 1990, 85(2-3), 169-173.

[127] Cooper, J.A.; Miller, G.J.; Bauer, K.A.; Morrissey, J.H.; Meade, T.W.; Howarth, D.J.; Barzegar, S.; Mitchell, J.P.; Rosenberg, R.D. Comparison of novel hemostatic factors and conventional risk factors for prediction of coronary heart disease. Circulation, 2000, 102(23), 2816-2822.

[128] Meade, T.W.; Mellows, S.; Brozovic, M.; Miller, G.J.; Chakrabarti, R.R.; North, W.R.; Haines, A.P.; Stirling, Y.; Imeson, J.D.; Thompson, S.G. Haemostatic function and ischaemic heart disease: principal results of the Northwick Park Heart Study. Lancet, 1986, 2(8506), 533-537.

[129] Miller, G.J.; Ireland, H.A.; Cooper, J.A.; Bauer, K.A.; Morrissey, J.H.; Humphries, S.E.; Esnouf, M.P. Relationship between markers of activated coagulation, their correlation with inflammation, and association with coronary heart disease (NPHSII). J. Thromb. Haemost., 2008, 6(2), 259-267.

[130] Campo, G.; Valgimigli, M.; Ferraresi, P.; Malagutti, P.; Baroni, M.; Arcozzi, C.; Gemmati, D.; Percoco, G.; Parrinello, G.; Ferrari, R.; Bernardi, F. Tissue factor and coagulation factor VII levels during acute myocardial infarction: association with genotype and adverse events. Arterioscler. Thromb. Vasc. Biol., 2006, 26(12), 2800-2806.

[131] Heinrich, J.; Balleisen, L.; Schulte, H.; Assmann, G.; van de Loo, J. Fibrinogen and factor VII in the prediction of coronary risk. Results from the PROCAM study in healthy men. Arterioscler. Thromb., 1994, 14(1), 54-59.

[132] Vischer, U.M. von Willebrand factor, endothelial dysfunction, and cardiovascular disease. J. Thromb. Haemost., 2006, 4, 1186-1193.

[133] Vischer, U.M.; Herrmann, F.R.; Peyrard, T.; Nzietchueng, R.; Benetos, A. Plasma von Willebrand factor and arterial aging. $J$. Thromb. Haemost., 2005, 3(4), 794-795.

[134] Blann, A.D.; Herrick, A.; Jayson, M.I. Altered levels of soluble adhesion molecules in rheumatoid arthritis, vasculitis and systemic sclerosis. Br. J. Rheumatol., 1995, 34(9), 814-819.

[135] Danesh, J.; Wheeler, J.G.; Hirschfield, G.M.; Eda, S.; Eiriksdottir, G.; Rumley, A.; Lowe, G.D.; Pepys, M.B.; Gudnason, V. Creactive protein and other circulating markers of inflammation in the prediction of coronary heart disease. N. Engl. J. Med., 2004, 350(14), 1387-1397.

[136] Haverkate, F.; Thompson, S.G.; Duckert, F. Haemostasis factors in angina pectoris; relation to gender, age and acute-phase reaction. Results of the ECAT Angina Pectoris Study Group. Thromb. Haemost., 1995, 73(4), 561-567.

[137] Folsom, A.R.; Conlan, M.G.; Davis, C.E.; Wu, K.K. Relations between hemostasis variables and cardiovascular risk factors in middle-aged adults. Atherosclerosis Risk in Communities (ARIC) Study Investigators. Ann. Epidemiol., 1992, 2(4), 481-494.

[138] Meigs, J.B.; Mittleman, M.A.; Nathan, D.M.; Tofler, G.H.; Singer, D.E.; Murphy-Sheehy, P.M.; Lipinska, I.; D'Agostino, R.B.; Wilson, P.W. Hyperinsulinemia, hyperglycemia, and impaired hemostasis: the Framingham Offspring Study. JAMA, 2000, 283(2), 221228 .

[139] Juhan-Vague, I.; Thompson, S.G.; Jespersen, J. Involvement of the hemostatic system in the insulin resistance syndrome. A study of 1500 patients with angina pectoris. The ECAT Angina Pectoris Study Group. Arterioscler. Thromb., 1993, 13(12), 1865-1873.

[140] Felmeden, D.C.; Blann, A.D.; Spencer, C.G.; Beevers, D.G.; Lip, G.Y. A comparison of flow-mediated dilatation and von Willebrand factor as markers of endothelial cell function in health and in hypertension: relationship to cardiovascular risk and effects of 
treatment: a substudy of the Anglo-Scandinavian Cardiac Outcomes Trial. Blood Coagul. Fibrinolysis, 2003, 14(5), 425-431.

[141] Rumley, A.; Lowe, G.D.; Sweetnam, P.M.; Yarnell, J.W.; Ford, R.P. Factor VIII, von Willebrand factor and the risk of major ischaemic heart disease in the Caerphilly Heart Study. Br. J. Haematol., 1999, 105(1), 110-116.

[142] Meade, T.W.; Cooper, J.A.; Stirling, Y.; Howarth, D.J.; Ruddock, V.; Miller, G.J. Factor VIII, ABO blood group and the incidence of ischaemic heart disease. Br. J. Haematol., 1994, 88(3), 601-607.

[143] Smith, F.B.; Lee, A.J.; Fowkes, F.G.; Price, J.F.; Rumley, A.; Lowe, G.D. Hemostatic factors as predictors of ischemic heart disease and stroke in the Edinburgh Artery Study. Arterioscler. Thromb. Vasc. Biol., 1997, 17(11), 3321-3325.

[144] Whincup, P.H.; Danesh, J.; Walker, M.; Lennon, L.; Thomson, A.; Appleby, P.; Rumley, A.; Lowe, G.D. von Willebrand factor and coronary heart disease: prospective study and meta-analysis. Eur. Heart J., 2002, 23(22), 1764-1770.

[145] Morange, P.E.; Simon, C.; Alessi, M.C.; Luc, G.; Arveiler, D.; Ferrieres, J.; Amouyel, P.; Evans, A.; Ducimetiere, P.; JuhanVague, I.; PRIME Study Group. Endothelial cell markers and the risk of coronary heart disease: the Prospective Epidemiological Study of Myocardial Infarction (PRIME) study. Circulation, 2004, 109(11), 1343-1348.

[146] Folsom, A.R.; Rosamond, W.D.; Shahar, E.; Cooper, L.S.; Aleksic, N.; Nieto, F.J.; Rasmussen, M.L.; Wu, K.K. Prospective study of markers of hemostatic function with risk of ischemic stroke. The Atherosclerosis Risk in Communities (ARIC) Study Investigators. Circulation, 1999, 100(7), 736-742.

[147] Reich, L.M.; Heiss, G.; Boland, L.L.; Hirsch, A.T.; Wu, K.; Folsom, A.R. Ankle-brachial index and hemostatic markers in the Atherosclerosis Risk in Communities (ARIC) study cohort. Vasc. Med., 2007, 12(4), 267-273.

[148] Frankel, D.S.; Meigs, J.B.; Massaro, J.M.; Wilson, P.W.; O'Donnell, C.J.; D'Agostino, R.B.; Tofler, G.H. Von Willebrand factor, type 2 diabetes mellitus, and risk of cardiovascular disease: the framingham offspring study. Circulation, 2008, 118(24), 25332539.

[149] Haines, A.P.; Howarth, D.; North, W.R.; Goldenberg, E.; Stirling, Y.; Meade, T.W.; Raftery, E.B.; Millar Craig, M.W. Haemostatic variables and the outcome of myocardial infarction. Thromb. Haemost., 1983, 50(4), 800-803.

[150] Jansson, J.H.; Nilsson, T.K.; Johnson, O. von Willebrand factor in plasma: a novel risk factor for recurrent myocardial infarction and death. Br. Heart J., 1991, 66(5), 351-355.

[151] Wiman, B.; Andersson, T.; Hallqvist, J.; Reuterwall, C.; Ahlbom, A.; deFaire, U. Plasma levels of tissue plasminogen activator/plasminogen activator inhibitor-1 complex and von Willebrand factor are significant risk markers for recurrent myocardial infarction in the Stockholm Heart Epidemiology Program (SHEEP) study. Arterioscler. Thromb. Vasc. Biol., 2000, 20(8), 2019-2023.

[152] Cortellaro, M.; Boschetti, C.; Cofrancesco, E.; Zanussi, C.; Catalano, M.; de Gaetano, G.; Gabrielli, L.; Lombardi, B.; Specchia, G.; Tavazzi, L.; Tremoli, E.; della Volpe, A.; Polli, E. and the PLAT Study Group*. The PLAT Study: hemostatic function in relation to atherothrombotic ischemic events in vascular disease patients. Principal results. PLAT Study Group. Progetto Lombardo AteroTrombosi (PLAT) Study Group. Arterioscler. Thromb., 1992, 12(9), 1063-1070.

[153] Montalescot, G.; Philippe, F.; Ankri, A.; Vicaut, E.; Bearez, E.; Poulard, JE.; Carrie, D.; Flammang, D.; Dutoit, A.; Carayon, A.; Jardel, C.; Chevrot, M.; Bastard, J.P.; Bigonzi, F.; Thomas, D. Early increase of von Willebrand factor predicts adverse outcome in unstable coronary artery disease: beneficial effects of enoxaparin. French Investigators of the ESSENCE Trial. Circulation, 1998, 98(4), 294-299.

[154] Ray, K.K.; Morrow, D.A.; Gibson, C.M.; Murphy, S.; Antman, E.M.; Braunwald, E. Predictors of the rise in vWF after ST elevation myocardial infarction: implications for treatment strategies and clinical outcome: An ENTIRE-TIMI 23 substudy. Eur. Heart J., 2005, 26(5), 440-446.

[155] Páramo, J.A.; Beloqui, O.; Colina, I.; Diez, J.; Orbe, J. Independent association of von Willebrand factor with surrogate markers of atherosclerosis in middle-aged asymptomatic subjects. J. Thromb. Haemost., 2005, 3(4), 662-664.

[156] Booth, N.A. Fibrinolysis and thrombosis. Baillieres Best Pract. Res. Clin. Haematol., 1999, 12(3), 423-433.
[157] Lee, K.W.; Lip, G.H. Effects of lifestyle on hemostasis, fibrinolysis and platelet reactivity. Arch. Intern. Med., 2003, 163, 2368-2392.

[158] Newby, D.E.; McLeod, A.L.; Uren, N.G.; Flint, L.; Ludlam, C.A.; Webb, D.J.; Fox, K.A.; Boon, N.A. Impaired coronary tissue plasminogen activator release is associated with coronary atherosclerosis and cigarette smoking: direct link between endothelial dysfunction and atherothrombosis. Circulation, 2001, 103(15), 1936-1941.

[159] Smith, D.T.; Hoetzer, G.L.; Greiner, J.J.; Stauffer, B.L.; DeSouza, C.A. Effects of ageing and regular aerobic exercise on endothelial fibrinolytic capacity in humans. J. Physiol., 2003, 546(Pt. 1), 289298.

[160] Yamamotoa, K.; Takeshitab, K.; Kojimac, T.; Takamatsua, J.; Saito, H. Aging and plasminogen activator inhibitor-1 (PAI-1) regulation: implication in the pathogenesis of thrombotic disorders in the elderly. Card. Res., 2005, 66, 276-285.

[161] Feener, E.P.; Northrup, J.M.; Aiello, L.P.; King, G.L. Angiotensin II induces plasminogen activator inhibitor-1 and -2 expression in vascular endothelial and smooth muscle cells. J. Clin. Invest., 1995, 95(3), 1353-1362.

[162] Brown, N.J.; Nakamura, S.; Ma, L.; Nakamura, I.; Donnert, E.; Freeman, M.; Vaughan, D.E.; Fogo, A.B. Aldosterone modulates plasminogen activator inhibitor-1 and glomerulosclerosis in vivo. Kidney Int., 2000, 58(3), 1219-1227.

[163] Thögersen, A.M.; Jansson, J.H.; Boman, K.; Nilsson. T.K.; Weinehall, L.; Huhtasaari, F.; Hallmans, G. High plasminogen activator inhibitor and tissue plasminogen activator levels in plasma precede a first acute myocardial infarction in both men and women: evidence for the fibrinolytic system as an independent primary risk factor. Circulation, 1998, 98(21), 2241-2247.

[164] Cushman, M.; Lemaitre, R.N.; Kuller, L.H.; Psaty, B.M.; Macy, E.M.; Sharrett, A.R.; Tracy, R.P. Fibrinolytic activation markers predict myocardial infarction in the elderly. The Cardiovascular Health Study. Arterioscler. Thromb. Vasc. Biol., 1999, 19(3), 493498.

[165] Lowe, G.D.; Danesh, J.; Lewington, S.; Walker, M.; Lennon, L.; Thomson, A.; Rumley, A.; Whincup, P.H. Tissue plasminogen activator antigen and coronary heart disease. Prospective study and meta-analysis. Eur. Heart J., 2004, 25(3), 252-259.

[166] Simmonds, R.E.; Hermida, J.; Rezende, S.M.; Lane, D.A. Haemostatic genetic risk factors in arterial thrombosis. Thromb. Haemost., 2001, 86(1), 374-385.

[167] van der Bom, J.G.; de Knijff, P.; Haverkate, F.; Bots, M.L.; Meijer, P.; de Jong, P.T.; Hofman, A.; Kluft, C.; Grobbee, D.E. Tissue plasminogen activator and risk of myocardial infarction. The Rotterdam Study. Circulation, 1997, 95(12), 2623-2637.

[168] Ridker, P.M.; Baker, M.T.; Hennekens, C.H.; Stampfer, M.J.; Vaughan, D.E. Alu-repeat polymorphism in the gene coding for tissue-type plasminogen activator (t-PA) and risks of myocardial infarction among middle-aged men. Arterioscler. Thromb. Vasc. Biol., 1997, 17(9), 1687-1690.

[169] Sakkinen, P.A.; Wahl, P.; Cushman, M.; Lewis, M.R.; Tracy, R.P. Clustering of procoagulation, inflammation, and fibrinolysis variables with metabolic factors in insulin resistance syndrome. Am. $J$. Epidemiol., 2000, 152(10), 897-907.

[170] Juhan-Vague, I.; Pyke, S.D.; Alessi, M.C.; Jespersen, J.; Haverkate, F.; Thompson, S.G. Fibrinolytic factors and the risk of myocardial infarction or sudden death in patients with angina pectoris. ECAT Study Group. European Concerted Action on Thrombosis and Disabilities. Circulation, 1996, 94(9), 2057-2063.

[171] Juhan-Vague, I.; Thompson, S.G.; Jespersen, J. Involvement of the hemostatic system in the insulin resistance syndrome. A study of 1500 patients with angina pectoris. The ECAT Angina Pectoris Study Group. Arterioscler. Thromb., 1993, 13(12), 1865-1873.

[172] Paraskevas, K.I.; Baker, D.M.; Vrentzos, G.E.; Mikhailidis, D.P. The role of fibrinogen and fibrinolysis in peripheral arterial disease. Thromb. Res., 2008, 122(1), 1-12.

[173] Lapolla, A.; Piarulli, F.; Sartore, G.; Rossetti, C.; Martano, L.; Carraro, P.; De Paoli, M.; Fedele, D. Peripheral artery disease in type 2 diabetes: the role of fibrinolysis. Thromb. Haemost., 2003, 89(1), 91-96.

[174] Killewich, L.A.; Gardner, A.W.; Macko, R.F.; Hanna, D.J.; Goldberg, A.P.; Cox, D.K.; Flinn, W.R. Progressive intermittent claudication is associated with impaired fibrinolysis. J. Vasc. Surg., 1998, 27(4), 645-650.

[175] Roller, R.E.; Janisch, S.; Carroll, V.; Kvas, E.; Pilger, E.; Binder, B.R.; Wojta, J. Changes in the fibrinolytic system in patients with 
peripheral arterial occlusive disease undergoing percutaneous transluminal angioplasty. Thromb. Res., 1999, 94(4), 241-247.

[176] Schneider, D.J.; Ricci, M.A.; Taatjes, D.J.; Baumann, P.Q.; Reese, J.C.; Leavitt, B.J.; Absher, P.M.; Sobel, B.E. Changes in arterial expression of fibrinolytic system proteins in atherogenesis. Arterioscler. Thromb. Vasc. Biol., 1997, 17(11), 3294-301.

[177] Sobel, B.E. Increased plasminogen activator inhibitor-1 and vasculopathy. A reconcilable paradox. Circulation, 1999, 99(19), 24962498.

[178] Carmeliet, P.; Moons, L.; Lijnen, R.; Janssens, S.; Lupu, F.; Collen, D.; Gerard, R.D. Inhibitory role of plasminogen activator inhibitor1 in arterial wound healing and neointima formation: a gene targeting and gene transfer study in mice. Circulation, 1997, 96(9), 31803191.

[179] Eren, M.; Painter, C.A.; Atkinson, J.B.; Declerck, P.J.; Vaughan, D.E. Age-dependent spontaneous coronary arterial thrombosis in transgenic mice that express a stable form of human plasminogen activator inhibitor-1. Circulation, 2002, 106(4), 491-496.

[180] Bogaty, P.; Robitaille, N.M.; Solymoss, S.; Boyer, L.; Auger, D.; Labbé, L.; Simard, S.; Rail, J.; Genest, J. Jr; Turgeon, J. Atherogenic, hemostatic, and other potential risk markers in subjects with previous isolated myocardial infarction compared with longstanding uncomplicated stable angina. Am. Heart J., 1998, 136(5), 884-893

[181] Salomaa, V.; Stinson, V.; Kark, J.D.; Folsom, A.R.; Davis, C.E.; $\mathrm{Wu}$, K.K. Association of fibrinolytic parameters with early atherosclerosis. The ARIC Study. Atherosclerosis Risk in Communities Study. Circulation, 1995, 91(2), 284-290.

[182] Szymanski, L.M.; Pate, R.R. Effects of exercise intensity, duration, and time of day on fibrinolytic activity in physically active men. Med. Sci. Sports Exerc., 1994, 26(9), 1102-1108.

[183] Rankinen, T.; Väisänen, S.; Penttilä, I.; Rauramaa, R. Acute dynamic exercise increases fibrinolytic activity. Thromb. Haemost., 1995, 73(2), 281-286.

[184] Barcelli, U.; Glas-Greenwalt, P.; Pollak, V.E. Enhancing effect of dietary supplementation with omega-3 fatty acids on plasma fibrinolysis in normal subjects. Thromb. Res., 1985, 39(3), 307-312.

[185] Emeis, J.J.; van Houwelingen, A.C.; van den Hoogen, C.M.; Hornstra, G. A moderate fish intake increases plasminogen activator inhibitor type-1 in human volunteers. Blood, 1989, 74(1), 233-237.

[186] Toft, I.; Bønaa, K.H.; Ingebretsen, O.C.; Nordøy, A.; Jenssen, T. Fibrinolytic function after dietary supplementation with omega3 polyunsaturated fatty acids. Arterioscler. Thromb. Vasc. Biol., 1997, 17(5), 814-819.

[187] Cefalu, W.T.; Schneider, D.J.; Carlson, H.E.; Migdal, P.; Gan Lim, L.; Izon, M.P.; Kapoor, A.; Bell-Farrow, A.; Terry, J.G.; Sobel, B.E. Effect of combination glipizide GITS/metformin on fibrinolytic and metabolic parameters in poorly controlled type 2 diabetic subjects. Diabetes Care, 2002, 25(12), 2123-2128.

[188] Kruszynska, Y.T.; Yu, J.G.; Olefsky, J.M.; Sobel, B.E. Effects of troglitazone on blood concentrations of plasminogen activator inhibitor 1 in patients with type 2 diabetes and in lean and obese normal subjects. Diabetes, 2000, 49(4), 633-639.

[189] Vaughan, D.E. Angiotensin and vascular fibrinolytic balance. Am. J. Hypertens., 2002, 15(1 Pt 2), 3S-8S.

[190] Usalan, C.; Buyukhatipoglu, H. A dynamic comparative study concerning the effects of angiotensin-converting enzyme inhibitors and aldosterone receptor blockers on the fibrinolytic system. Clin. Appl. Thromb. Hemost., 2008, 14(2), 203-209.

[191] Wang. L.; Rockwood, J.; Zak, D.; Devaraj, S.; Jialal, I. Simvastatin reduces circulating plasminogen activator inhibitor 1 activity in volunteers with the metabolic syndrome. Metab. Syndr. Relat. Disord., 2008, 6(2), 149-152.

[192] Ludwig, S.; Dharmalingam, S.; Erickson-Nesmith, S.; Ren, S.; Zhu, F.; Ma, G.M.; Zhao, R.; Fenton, J.W. 2 ${ }^{\text {nd }}$; Ofosu, F.A.; Velthuis, H.T.; van Mierlo, G.; Shen, G.X. Impact of simvastatin on hemostatic and fibrinolytic regulators in Type 2 diabetes mellitus. Diabetes Res. Clin. Pract., 2005, 70(2), 110-118.

[193] Lopez, S.; Peiretti, F.; Bonardo, B.; Juhan-Vague, I.; Nalbone, G. Effect of atorvastatin and fluvastatin on the expression of plasminogen activator inhibitor type-1 in cultured human endothelial cells. Atherosclerosis, 2000, 152, 359-366.

[194] Demyanets, S.; Kaun, C.; Rychli, K.; Rega, G.; Pfaffenberger, S.; Afonyushkin, T.; Bochkov, V.N.; Maurer, G.; Huber, K.; Wojta, J. The inflammatory cytokine oncostatin $\mathrm{M}$ induces PAI-1 in human vascular smooth muscle cells in vitro via PI 3-kinase and ERK1/2- dependent pathways. Am. J. Physiol. Heart Circ. Physiol., 2007, 293(3), H1962-H1968.

[195] Gaffney, P.J.; Brasher, M. Subunit structure of the plasmin-induced degradation products of crosslinked fibrin. Biochim. Biophys. Acta, 1973, 295(1), 308-313.

[196] Rumley, A.; Emberson, J.R.; Wannamethee, S.G.; Lennon, L.; Whincup, P.H.; Lowe, G.D. Effects of older age on fibrin D-dimer, C-reactive protein, and other hemostatic and inflammatory variables in men aged 60-79 years. J. Thromb. Haemost., 2006, 4(5), 982-987.

[197] Lee, A.J.; Fowkes, G.R.; Lowe, G.D.; Rumley, A. Determinants of fibrin D-dimer in the Edinburgh Artery Study. Arterioscler. Thromb. Vasc. Biol., 1995, 15(8), 1094-1097.

[198] Giansante, C.; Fiotti, N.; Cattin, L.; Da Col, P.G.; Calabrese, S. Fibrinogen, D-dimer and thrombin-antithrombin complexes in a random population sample: relationships with other cardiovascular risk factors. Thromb. Haemost., 1994, 71, 581-586.

[199] Danesh, J; Whincup, P.; Walker, M.; Lennon, L.; Thomson, A.; Appleby, P.; Rumley, A.; Lowe, G.D. Fibrin D-dimer and coronary heart disease: prospective study and meta-analysis. Circulation, 2001, 103(19), 2323-2327.

[200] Lowe, G.D.; Rumley, A.; McMahon, A.D.; Ford, I.; O'Reilly, D.S.; Packard, C.J.; West of Scotland Coronary Prevention Study Group. Interleukin-6, fibrin D-dimer, and coagulation factors VII and XIIa in prediction of coronary heart disease. Arterioscler. Thromb. Vasc. Biol., 2004, 24(8), 1529-1534.

[201] Folsom, A.R.; Aleksic, N.; Park, E.; Salomaa, V; Juneja, H.; Wu, K.K. Prospective study of fibrinolytic factors and incident coronary heart disease: the Atherosclerosis Risk in Communities (ARIC) Study. Arterioscler. Thromb. Vasc. Biol., 2001, 21(4), 611-617.

[202] Kruskal, J.B.; Commerford, P.J.; Franks, J.J.; Kirsch, R.E. Fibrin and fibrinogen-related antigens in patients with stable and unstable coronary artery disease. N. Engl. J. Med., 1987, 317(22), 13611365 .

[203] Francis, C.W.; Connaghan, D.G.; Scott, W.L.; Marder, V.J. Increased plasma concentration of cross-linked fibrin polymers in acute myocardial infarction. Circulation, 1987, 75(6), 1170-1177.

[204] Tanaka, M.; Suzuki, A. Hemostatic abnormalities in acute myocardial infarction as detected by specific blood markers. Thromb. Res., 1994, 76(3), 289-298.

[205] Lee, A.J.; Fowkes, F.G.; Lowe, G.D.; Rumley. A. Fibrin D-dimer, haemostatic factors and peripheral arterial disease. Thromb. Haemost., 1995, 74(3), 828-832.

[206] Lowe, G.D.; Yarnell, J.W.; Rumley, A.; Bainton, D.; Sweetnam, P.M. C-reactive protein, fibrin D-dimer, and incident ischemic heart disease in the Speedwell study: are inflammation and fibrin turnover linked in pathogenesis? Arterioscler. Thromb. Vasc. Biol., 2001, 21(4), 603-610.

[207] Lowe, G.D.; Sweetnam, P.M.; Yarnell, J.W.; Rumley, A.; Rumley, C.; Bainton, D.; Ben-Shlomo, Y. C-reactive protein, fibrin Ddimer, and risk of ischemic heart disease: the Caerphilly and Speedwell studies. Arterioscler. Thromb. Vasc. Biol., 2004, 24(10), 1957-1962.

[208] Milionis, H.J.; Winder, A.F.; Mikhailidis, D.P. Lipoprotein (a) and stroke. J. Clin. Pathol., 2000, 53(7), 487-496.

[209] Kostner, K.M.; Kostner, G.M. The physiological role of lipoprotein (a). Drug News Perspect., 2002, 15(2), 69-77.

[210] Bartens, W.; Wanner, C. Lipoprotein(a): new insights into an atherogenic lipoprotein. Clin. Investig., 1994, 72(8), 558-567.

[211] Kronenberg, F.; Kronenberg, M.F.; Kiechl, S.; Trenkwalder, E.; Santer, P.; Oberhollenzer, F.; Egger, G.; Utermann, G.; Willeit, J. Role of lipoprotein(a) and apolipoprotein(a) phenotype in atherogenesis: prospective results from the Bruneck study. Circulation, 1999, $100(11), 1154-1160$.

[212] Danesh, J.; Collins, R.; Peto, R. Lipoprotein(a) and coronary heart disease. Meta-analysis of prospective studies. Circulation, 2000, 102(10), 1082-1085.

[213] Bennet, A.; Di Angelantonio, E.; Erqou, S.; Eiriksdottir, G.; Sigurdsson, G.; Woodward, M.; Rumley, A.; Lowe, G.D.; Danesh, J.; Gudnason, V. Lipoprotein(a) levels and risk of future coronary heart disease: large-scale prospective data. Arch. Intern. Med., 2008, 168(6), 598-608.

[214] Scanu, A.M. Lipoprotein (a). A genetic risk factor for premature coronary heart disease. JAMA, 1992, 267(24), 3326-3329.

[215] Gómez, M.; Valle, V.; Arós, F.; Sanz, G.; Sala, J.; Fiol, M.; Bruguera, J.; Elosua, R.; Molina, L.; Martí, H.; Covas, M.I.; Ro- 
dríguez-Llorián, A.; Fitó, M.; Suárez-Pinilla, M.A.; Amezaga, R.; Marrugat, J.; FORTIAM group of researchers. Oxidized LDL, lipoprotein (a) and other emergent risk factors in acute myocardial infarction (FORTIAM study). Rev. Esp. Cardiol., 2009, 62(4), 373382.

[216] Saely, C.H.; Koch, L.; Schmid, F.; Marte, T.; Aczel, S.; Langer, P.; Hoefle, G.; Drexel, H. Lipoprotein(a), type 2 diabetes and vascular risk in coronary patients. Eur. J. Clin. Invest., 2006, 36(2), 91-97.

[217] Moliterno, D.J.; Jokinen, E.V.; Miserez, A.R.; Lange, R.A.; Willard, J.E.; Boerwinkle, E.; Hillis, L.D.; Hobbs, H.H. No association between plasma lipoprotein(a) concentrations and the presence or absence of coronary atherosclerosis in African-Americans. Arterioscler. Thromb. Vasc. Biol., 1995, 15(7), 850-855.

[218] Ridker, P.M.; Hennekens, C.H.; Stampfer, M.J. A prospective study of lipoprotein (a) and the risk of myocardial infarction. JAMA, 1993, 270(18), 2195-2199.

[219] Hobbs, H.H.; White, A.L. Lipoprotein (a): intrigues and insights. Curr. Opin. Lipidol., 1999, 10(3), 225-236.

[220] Marcovina, S.M.; Albers, J.J.; Wijsman, E.; Zhang, Z.; Chapman, N.H.; Kennedy, H. Differences in Lp[a] concentrations and apo[a] polymorphs between black and white Americans. J. Lipid Res., 1996, 37(12), 2569-2585.

[221] Moliterno, D.J.; Jokinen, E.V.; Miserez, A.R.; Lange, R.A.; Willard, J.E.; Boerwinkle, E.; Hillis, L.D.; Hobbs, H.H. No association between plasma lipoprotein(a) concentrations and the presence or absence of coronary atherosclerosis in African-Americans. Arterioscler. Thromb. Vasc. Biol., 1995, 15(7), 850-855.

[222] von Eckardstein, A.; Schulte, H.; Cullen, P.; Assmann, G. Lipoprotein(a) further increases the risk of coronary events in men with high global cardiovascular risk. J. Am. Coll. Cardiol., 2001, 37(2), 434-439.
[223] Ganotakis, E.S.; Vrentzos, G.E.; Gazi, I.F.; Papadakis, J.A.; Jagroop, A.; Paraskevas, K.I.; Nair, D.R.; Mikhailidis, D.P. Fibrinogen, lipoprotein (a), albumin and bilirubin F-L-A-B) levels and cardiovascular risk calculated using the Framingham equation. In Vivo, 2007, 21(4), 685-694.

[224] Kullo, I.J.; Ballantyne, C.M. Conditional risk factors for atherosclerosis. Mayo Clin. Proc., 2005, 80(2), 219-230.

[225] Dirisamer, A.; Widhalm, H.; Aldover-Macasaet, E.; Molzer, S.; Widhalm, K. Elevated Lp(a) with a small apo(a) isoform in children: risk factor for the development of premature coronary artery disease. Acta Paediatr., 2008, 97(12), 1653-1657.

[226] Carlson, L.; Hamsten, A.; Asplund, A. Pronounced lowering of serum levels of lipoprotein $\mathrm{Lp}(\mathrm{a})$ in hyperlipidemic subjects treated with nicotinic acid. J. Intern. Med., 1989, 226, 271-276.

[227] Farish, E.; Spowart, K.; Barnes, J.F.; Fletcher, C.D.; Calder, A.; Brown, A.; Hart, D.M. Effects of postmenopausal hormone replacement therapy on lipoproteins including lipoprotein(a) and LDL subfractions. Atherosclerosis, 1996, 126(1), 77-84.

[228] Mikhailidis, D.P.; Ganotakis, E.S.; Spyropoulos, K.A.; Jagroop, I.A.; Byrne, D.J.; Winder, A.F. Prothrombotic and lipoprotein variables in patients attending a cardiovascular risk management clinic: response to ciprofibrate or lifestyle advice. Int. Angiol., 1998, 17(4), 225-233.

[229] Papadakis, J.A.; Ganotakis, E.S.; Jagroop, I.A.; Mikhailidis, D.P.; Winder, A.F. Effect of hypertension and its treatment on lipid, lipoprotein(a), fibrinogen, and bilirubin levels in patients referred for dyslipidemia. Am. J. Hypertens., 1999, 12(7), 673-681.

[230] Hunninghake, D.B.; Stein, E.A.; Mellies, M.J. Effects of one year of treatment with pravastatin, an HMG-CoA reductase inhibitor, on lipoprotein (a). J. Clin. Pharmacol., 1993, 33(6), 574-580.

(C) Lioudaki and Ganotakis; Licensee Bentham Open.

This is an open access article licensed under the terms of the Creative Commons Attribution Non-Commercial License (http://creativecommons.org/licenses/ by-nc/3.0/) which permits unrestricted, non-commercial use, distribution and reproduction in any medium, provided the work is properly cited. 